\title{
Heterolithic meandering-channel deposits from the Neoproterozoic of NW Scotland: Implications for palaeogeographic reconstructions of Precambrian sedimentary environments
}

\author{
Mauricio G.M. Santos ${ }^{\mathrm{a}, \mathrm{b}, *}$, Geraint Owen ${ }^{\mathrm{c}}$ \\ a Department of Applied Geology, IGCE, UNESP, Av. 24-A, 1515, Rio Claro, SP 13506-900, Brazil \\ ${ }^{\mathrm{b}}$ Fluvial Research Group, University of Leeds, Leeds LS2 9JT, England, UK

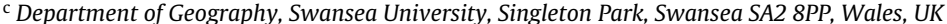

\section{A R T I C L E I N F O}

\section{Article history:}

Received 12 July 2015

Received in revised form 16 October 2015

Accepted 7 November 2015

Available online 14 November 2015

\section{Keywords:}

Fluvial deposits

Meandering rivers

Precambrian

Pre-vegetation

Neoproterozoic

Torridonian

Scotland

\begin{abstract}
A B S T R A C T
Pre-Silurian fine-grained meandering river deposits are apparently rare in the rock record. Most modernday river dynamics are influenced by vegetation through bank stabilization, fine-grained sediment production and retention, and runoff control, leading to the development of highly sinuous, singlechannel systems. In contrast, pre-vegetation river dynamics are poorly understood, in part because there are no modern-day analogues for completely non-vegetated meandering river systems, particularly under humid climates. Some models attribute the paucity of fine-grained sediments described from studies of pre-vegetation fluvial deposits to lower rates of chemical weathering in the absence of land plants. The architecture of precambrian, fine-grained meandering stream deposits is here described for the first time.

The Allt na Béiste Member at the base of the Applecross Formation of the Torridon Group (Neoproterozoic, NW Scotland) is characterized by heterolithic deposits, preserving a varied suite of fluvial forms including inclined heterolithic strata, lateral-accretion sets, up to $8 \mathrm{~m}$-thick muddy floodplain deposits with preserved crevasse-splays. Successions of laterally-accreting strata are interbedded with metre-scale channel-fill sandstones, in a succession up to $190 \mathrm{~m}$-thick related to the early stages of the Applecross Formation fluvial system, as large-scale rivers buried the Lewisian palaeovalleys over which fluvial and lacustrine sediments of the Diabaig Formation had been deposited. The lacustrine fine-grained sediments, coupled with relatively low gradients of the shallow lacustrine environments and denuded, highly weathered Lewisian basement, apparently provided considerable amounts of fine-grained sediment which added sufficient cohesion to this fluvial system to induce the adoption of laterally-migrating, meandering channel planforms at the expense of multi-thread braided channels.

Our data suggest that, given appropriate conditions, pre-vegetation meandering channel planforms were indeed able to develop, without the buffering effects of land plants. The paucity of fine-grained sediments in the pre-vegetation rock record may be more a consequence of preservation-related issues than the actual paucity of such sediments. These results provide novel insights into the characteristics of Earth's landscape prior to the Silurian, and provide potential analogues for meandering channels interpreted from satellite imagery of Mars.
\end{abstract}

(C) 2015 Elsevier B.V. All rights reserved.

\section{Introduction}

Precambrian rivers functioned in the absence of significant interaction between sedimentological processes and biological activity on land. Deposits of pre-vegetation fluvial systems share many characteristics with those of post-vegetation fluvial systems

* Corresponding author at: Department of Applied Geology, IGCE, UNESP, Av. 24-A, 1515, Rio Claro, SP 13506-900, Brazil. Tel.: +55 11982446657.

E-mail address: mauriciogmsantos@gmail.com (M.G.M. Santos). developed under arid climates (Schumm, 1968), since these are the only modern climatic conditions in which vegetation is sparse or mostly absent. Pre-vegetation rivers, however, are interpreted to have developed within relatively barren continental environments under a wide variety of climatic and hydrological conditions (Long, 1978, 2004, 2006, 2011; Eriksson et al., 1998, 2006, 2013). Vegetation appeared in alluvial environments in the Mid-Palaeozoic and is a major control in most modern-day depositional systems (Corenblit and Steiger, 2009), influencing soil production, run-off control, surface roughness and bank stabilization, and allowing the development and preservation of stable floodplain deposits 
(Cotter, 1978; Gibling et al., 2014). The interpretation of pre-vegetation fluvial systems is therefore a challenge for sedimentologists since there are no modern analogues for non-vegetated alluvial systems under most climatic settings, and there is a lack of specific analytical methods and criteria to account for the particular features of these systems. Their interpretation consequently requires detailed architectural modelling, including the collection of large datasets recording the orientations of different sedimentary surfaces in relation to each other (Long, 2011). Recent detailed studies on the precambrian Ellice Formation demonstrated higher geomorphic variability than envisaged by current models for prevegetation fluvial systems (Ielpi and Rainbird, 2015).

According to present models for pre-vegetation fluvial systems, most were multi-channel, braided streams (Schumm, 1968) which rapidly widened in response to increasing discharge due to the lack of sediment cohesion (Wolman and Brush, 1961). This behaviour resulted in channels with high width-to-depth ratios, classified as the sheet-braided fluvial style (Cotter, 1978; Fuller, 1985). Most published studies of pre-vegetation fluvial systems describe a paucity of fine-grained sediments, and most sedimentary structures and facies associations are attributed to bedload transport in braided streams (Hjellbakk, 1997; Long, 2006, 2011; Marconato et al., 2014; Røe, 1987; Røe and Hermansen, 1993; Santos et al., 2014; Selley, 1969; Sønderholm and Tirsgaard, 1998; Tirsgaard and Øxnevad, 1998; Went, 2005, 2013; Williams and Foden, 2011; Winston, 1978). Published interpretations of fine-grained meandering systems are based primarily on supposed fining-upwards trends in channel deposits (e.g. Sweet, 1988). Depositional models for non-vegetated meandering river deposits are scarce, no fine-grained meandering river deposits have been described in the literature, and examples of sandy and gravelly meandering systems are very rare (Long, 2011). Crevasse-spay deposits are also very rare, and have been recorded adjacent to ephemeral sandy-meandering systems (Long, 2011). Braided systems with deep channels and well-developed levées have been described in the upper successions Applecross Formation (Ielpi and Ghinassi, 2015).

Interpretations of meandering channel planforms from outcrop studies are largely based on the recognition of laterally accreted fluvial forms and their abundance in relation to other forms (Allen, 1964; Miall, 1996). Lateral accretion sets are typically heterolithic and characterized by sigmoidal profiles with a basal scoured surface. Fining-upward cycles are common, grading upward into siltstones and heterolithic strata (Allen, 1965; Leeder, 1973). Studies of modern and ancient strata suggest that such features form through the lateral growth of point bars in high-sinuosity channel systems of various scales and settings (Thomas et al., 1987). A sharp increase in the reported frequency of preservation of inclined heterolithic stratification in lateral accretion sets in fluvial deposits from the Silurian onwards suggests that meandering river systems become more frequent during the Palaeozoic, at the same time as land plants colonized the continents (Cotter, 1978; Davies and Gibling, 2010). Those data suggest that meandering channel planforms are closely linked to the presence of vegetation in the alluvial environment, and that prior to the development of vegetation on the continents there was little variation in river characteristics. Interestingly, meandering channel planforms have recently been described from Mars (Nußbaumer, 2009; Schon et al., 2012), adding a range of possible scenarios for pre-vegetation river systems.

We present here the results of detailed outcrop studies from the Allt na Béiste Member at the base of the Neoproterozoic Applecross Formation of the Torridonian succession in NW Scotland, UK (Stewart, 2002; Owen and Santos, 2014). These fluvial deposits display a range of depositional architecture including lenticular bedding with lateral accretion surfaces, and macroforms characterized by inclined heterolithic strata. Fine-grained deposits are thick (up to $8 \mathrm{~m}$ ) compared with other pre-vegetation fluvial deposits and incorporate several facies associations, crevasse-channel and -splay deposits, and a range of soft-sediment deformation features. These characteristics indicate that parts of the river system formed discrete channel and floodplain elements, and that some channels had meandering planforms, results that contrast with other prevegetation fluvial systems described in the literature to date.

The object of this paper is to present the first description of the depositional architecture of Precambrian heterolithic meandering fluvial channels, and suggest local and regional controls that enabled rivers to meander in the absence of land plants. These observations provide novel insights into aspects of Earth's landscape prior to the early Palaeozoic, and represent potential field-based analogues for recently-interpreted channels on Mars. This work contributes to the understanding of pre-vegetation fluvial systems, and contributes to developing a methodology for the study of precambrian fluvial deposits. The description of the geometry of the heterolithic facies association contributes to understanding the nature of barriers to fluid migration in precambrian rocks.

\section{Geological setting}

The Mesoproterozoic to Neoproterozoic "Torridonian" rocks of NW Scotland, UK, comprise a $>11 \mathrm{~km}$-thick continental siliciclastic succession limited to the East by the Moine Thrust and to the West by the Outer Hebrides Fault Zone, and unconformably overlain by Cambrian rocks (Fig. 1). "Torridonian" is an informal stratigraphical unit comprising the Stoer, Sleat and Torridon Groups (Stewart, 2002), sometimes referred to as the Torridonian Supergroup (e.g. Williams and Foden, 2011). The Mesoproterozoic Stoer Group (up to $2 \mathrm{~km}$ thick) unconformably overlies Archean to Lower Proterozoic Lewisian Gneiss and is separated by an angular unconformity from the more widespread Neoproterozoic Torridon Group (Stewart, 1969). This is up to $7 \mathrm{~km}$ thick and comprises the Diabaig, Applecross, Aultbea and Cailleach Head Formations (Selley, 1965, 1969; Williams, 1969, 2001; Owen, 1995, 1996). The original size and shape of the Torridon Group basin is impossible to constrain because its present-day extent is bounded by post-depositional faults (Krabbendam et al., 2008) and its syndepositional limits are concealed or eroded. Its tectonic setting is

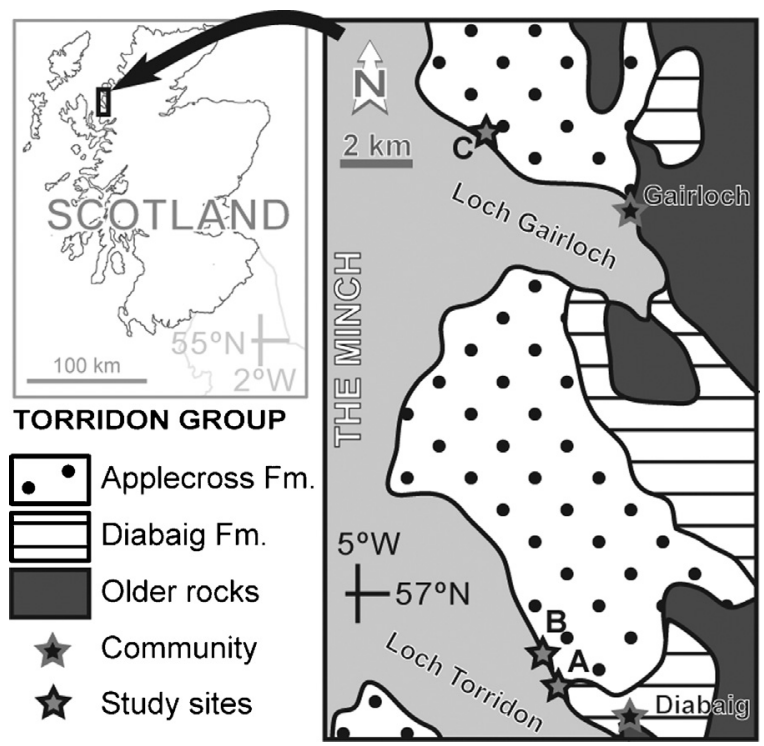

Fig. 1. Map of the study area showing the outcrop of the Torridon Group and older rocks in the coastal sections of Loch Torridon and Loch Gairloch (NW Highlands, Scotland). The Allt na Béiste Member comprises the basal part of the Applecross Formation which overlies the Diabaig Formation. 
disputed; interpretations include an asymmetrical rift basin with a faulted margin near the present-day Outer Hebrides (Stewart, 1982, 2002; Williams, 1969, 2001), a thermal sag basin (Nicholson, 1993), a post-Grenvillian extensional collapse basin (Turnbull et al., 1996; Williams and Foden, 2011), and a Grenville Orogeny-related foreland basin (Rainbird et al., 2001; Kinnaird et al., 2007; Krabbendam et al., 2008).

Massive, coarse-grained breccias at the base of the $600 \mathrm{~m}$ thick Diabaig Formation pass laterally and upwards into grey shales, silty mudstones and rippled, tabular-bedded red sandstones (Stewart, 1988). The depositional setting was the infilling of Lewisian palaeovalleys, initially by locally derived, coarse-grained sediments, followed by deposition in shallow lakes and rivers (Stewart, 2002). Zircon provenance analysis shows the youngest grains to be of late Mesoproterozoic age (1093 \pm 34 Ma, Kinnaird et al., 2007), while Rb-Sr whole-rock isotopic determination gives a depositional age of $994 \pm 48$ Ma (Turnbull et al., 1996). Tabular centimetre- to decimetre-scale beds of symmetrically rippled sandstone alternating with mudstone pass upward into tabular sandstone beds with small- to large-scale cross-bedding at the base of the Applecross Formation, recording a change from event deposition in a shallow lake to the onset of a large-scale fluvial system.

The Applecross Formation includes over $3000 \mathrm{~m}$ of predominantly red, coarse-grained arkosic sandstones and pebble conglomerates, with very rare fine-grained deposits (Stewart, 2002). Rb-Sr whole-rock isotopic analysis has yielded a depositional age of $977 \pm 39 \mathrm{Ma}$ (Turnbull et al., 1996) and youngest detrital zircon data give $1060 \pm 18 \mathrm{Ma}$ (Rainbird et al., 2001). These sediments have been interpreted by some as transversal fluvial megafan systems draining supracrustal and crystalline terrains of mainly late Palaeoproterozoic age to the West of the present-day outcrop, forming a broad alluvial plain related to a post-Grenvillian extensional basin (Williams, 1969, 2001; Williams and Foden, 2011). The depositional architecture is typified by laterallyextensive tabular sandstone bodies with high width-to-depth ratios which resemble the typical pre-vegetation architecture classified by Cotter (1978) as sheet-braided. Williams (1966), working in the NW of the outcrop, described pebbly sandstone and conglomerate in laterally-accreted cross-sets up to $2 \mathrm{~m}$ thick with moderate dip and internal cross-stratification related to channel bars or point bars of migrating braided channels, and inferred that flow conditions were very variable. He proposed periods of quiet water when mud cross-strata and low-dipping, fine-grained sands filled channels and were later removed by recurring strong currents, and noted point bars with relatively low dips which rarely reached the angle of repose of saturated sands. Nicholson (1993), working over most of the Applecross Formation extent, found evidence for channels of the order of $10 \mathrm{~m}$ deep and related these to longer, deeper, perennial river systems. The architectural characteristics of the upper parts of the Applecross Formation, in the Stoer Peninsula, are interpreted as channelized gravelly-sandy braided systems, and include local non-heterolithic lateral accretion elements, interpreted as parts of inchannel braid bars (Ielpi and Ghinassi, 2015).

The object of this study is the Allt na Béiste Member at the base of the Applecross Formation. Restricted to the Allt na Béiste Member are relatively thick units of fine-grained and heterolithic deposits, as described by Peach et al. (1907), which suggest continuity of deposition from the underlying Diabaig Formation. A fluviatile origin for the Allt na Béiste Member was proposed by Stewart (2002), who redefined the base of the Applecross Formation to the base of this member. The differences between the Allt na Béiste Member and the underlying Diabaig Formation were described by Stewart (2002), including: (1) modal mineralogy of sandstones (similarity of the Allt na Béiste Member deposits to those preserved in the Applecross Formation but different from those preserved in the Diabaig Formation); (2) provenance analyses (presence of distantly-sourced chert and porphyry pebbles in the Allt na Béiste Member and Applecross Formation, as opposed to the proximalsourced Diabaig Formation); (3) feldspar content (content around $25 \%$ and mostly potassic composition in the Allt na Béiste Member as opposed to the content of up to $40 \%$ and mostly by plagioclases derived from local basement gneiss); and (4) colour (shales in the Allt na Béiste Member being reddish-brown and greyish red, as opposed to the Diabaig Formation's grey shales). The type section near the Allt na Béiste stream at Lower Diabaig, on the north side of Loch Torridon, is approximately $25 \mathrm{~m}$ thick, but the thickness is highly variable, reaching almost $200 \mathrm{~m}$ near Gairloch (Stewart, 2002). Although Kinnaird et al. (2007) suggested on the basis of zircon geochronology that the Diabaig-Applecross contact represents a hiatus of the order of a few million years, detailed sedimentological studies point to a transition from the Diabaig lacustrine shales and basin-border fanglomerate system to the large-scale fluvial system of the Applecross Formation (Selley, 1965; Stewart, 2002; Williams and Foden, 2011). It is distinguished from the remainder of the Applecross Formation by finer grain-size, fewer pebbles, abundance of preserved mudstone, and includes heterolithic deposits with apparent fining-upward cycles as well as units with distinctive lenticular bedding geometries (Stewart, 2002).

\section{Methodology}

Stratigraphical sections in the Allt na Béiste Member were logged at the type section are at Diabaig and near Big Sand fishing station W of Gairloch, and photomosaics of key architectural panels were annotated in the field at Diabaig. The classification of fluvial forms is based on the relationship between external form and internal structures (Miall, 1996; Long, 2006). Palaeoflow indicators from cross-stratification (0th-order) were measured and compared with the dip directions of major internal surfaces (2nd- to 3rd-order) and lower bounding surfaces (4th- to 5 th-order). The data are plotted as rose diagrams and analyzed along with photographic panels and field sketches to identify different fluvial forms, each characterized by distinct characteristics of sedimentary facies associations (Table 1) and external geometries. Characterization of architectural elements was based on the relationship between external and internal surfaces (Table 2). Although Stewart (2002) describes a regional dip of $20^{\circ}$ to $300^{\circ}$, local dips measured from interbedded mudstones and sandstones at Diabaig were much lower, measured at $2-4^{\circ}$ to $340^{\circ}$. Due to these low values, no adjustments were made for tectonic tilt for the data from Diabaig. Regional tilt values quoted by Stewart (2002) were, however, applied to data from other localities, such as Gairloch, as described below.

\section{Results: sedimentology of the Allt na Béiste Member}

The Allt na Béiste Member comprises red to brown, fine- to coarse-grained arkosic sandstones and granule to pebble conglomerates interbedded with red to dark grey siltstones and mudstones with lenticular to tabular bedding (Fig. 2). In the type section, the transitional relationship with the underlying Diabaig Formation is clear in an almost continuous succession. Cross-stratified sandstones are generally organized in lenticular bodies alternating with laterally-extensive units of siltstone and shale approximately 5-8 m thick. It shares with the remainder of the Applecross Formation the dominance of red trough cross-stratified coarse-grained sandstones with pebbles of various lithologies, and the presence of soft-sediment deformation in the coarser members (Owen, 1995, 1996), but lacks the dominantly tabular geometry of sandstone units, the large-scale fluvial forms, and large-scale, complex forms of soft-sediment deformation (e.g. Nicholson, 1993; Owen, 1996; Selley, 1969; Williams, 1969). Our data supports the fluviatile origin 
Table 1

Main facies associations.

\begin{tabular}{|c|c|c|}
\hline Facies association & Description & Interpretation \\
\hline \multicolumn{3}{|l|}{ Channel deposits } \\
\hline FAC01 & $\begin{array}{l}\text { Medium- to coarse-grained sandstones presenting planar cross } \\
\text { stratification, preserved in sets of } 15 \mathrm{~cm} \text { to up to } 1 \mathrm{~m} \text { thick, and } \\
\text { organized in cosets of up to } 2 \mathrm{~m} \text { thick. Present sparse intraformational } \\
\text { mudclasts of up to } 1 \mathrm{~cm} \text { long. }\end{array}$ & $\begin{array}{l}\text { Migration of bar forms during peak-flow events under } \\
\text { lower-flow regime. }\end{array}$ \\
\hline FAC02 & $\begin{array}{l}\text { 10-25 cm-thick silty-mudstone lenses intercalated with } 7-20 \mathrm{~cm} \text {-thick } \\
\text { medium-grained, low-angle planar cross-stratified sandstone lenses. }\end{array}$ & $\begin{array}{l}\text { Alternated deposition of peak-flow stages recorded by the } \\
\text { low-angle bedforms, with fine-grained sediments settling out } \\
\text { during periods of relatively more quiet flow energy. }\end{array}$ \\
\hline FAC03 & $\begin{array}{l}\text { Planar cross-stratified, medium- and coarse-grained sandstones } \\
\text { preserved in } 20-80 \mathrm{~cm} \text {-thick cosets laterally associated with up to } \\
20-130 \mathrm{~cm} \text {-thick cosets of trough cross-stratified coarse-grained } \\
\text { sandstones with granules and scattered extraformational pebbles up } \\
\text { to } 3 \mathrm{~cm} \text { (mostly of vein quartz and k-feldspar; angular to sub-angular). } \\
\text { Abundant intraformational mudclasts. Some of the trough } \\
\text { cross-stratified sandstones are capped by undulated lenses of } \\
\text { fine-grained sandstone at upper part preserving upper part of dune; } \\
\text { they are } 1-8 \mathrm{~cm} \text { thick and up to } 30 \mathrm{~cm} \text { long. }\end{array}$ & $\begin{array}{l}\text { Migration of two- and three-dimensional dunes in channel } \\
\text { bottom. Such lenses are interpreted as to record waning flow } \\
\text { after peak discharges. }\end{array}$ \\
\hline FAC04 & $\begin{array}{l}\text { Horizontally stratified coarse-grained sandstones in 30-120 cm-thick, } \\
\text { laterally-extensive sandstone lenses. }\end{array}$ & $\begin{array}{l}\text { Channel shallowing, with deposition of low-relief bedforms } \\
\text { under upper flow regime. }\end{array}$ \\
\hline FAC5 & $\begin{array}{l}\text { Soft sediment deformation features consisting of unharmonic folds } \\
\text { with chaotic organization. Deformation disrupts series of sets of } \\
\text { coarse-grained to pebbly sandstones presenting trough } \\
\text { cross-stratification and may be truncated by overlying erosional } \\
\text { surface or diminishes upwards. Deformation occur in isolated, }\end{array}$ & $\begin{array}{l}\text { Liquefaction occurring in two different settings: on shallow } \\
\text { sediments under the influence of river flow, and on buried } \\
\text { sediments. The former is a combination of current-shear drag } \\
\text { and liquefaction, while the latter is related to underground } \\
\text { water up-welling. }\end{array}$ \\
\hline
\end{tabular}
sediments are typically non-deformed.

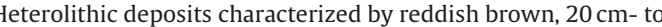
$1 \mathrm{~m}$-thick planar-cross-stratified, coarse-grained sandstones alternated with 1-10 cm-thick lenses of dark grey mudstone. Such facies association is characterized by inclined beddings which dip in the direction of lateral channel migration.

FAC7 Medium-grained sandstone with climbing ripples, $4-8 \mathrm{~cm}$, asymmetrical ripples and sparse granules associated with laminated, rippled siltstone and mudstone. Basal surface preserves bedform relief of dunes.

Floodplain deposits FAF01
Laminated mudstone, grey colour, $15-200 \mathrm{~cm}$ thick, presenting $2 \mathrm{~mm}$ to $4 \mathrm{~cm}$-thick medium- to very coarse-sandstone with low-angle ripple lamination in tabular to lenticular bodies; sandstone lenses are locally characterized by pinch and swell structures representing low-amplitude ripples and may present rippled top; blobs of granules and small pebbles (up to $4 \mathrm{~cm}$ ) blobs up to $5 \mathrm{~mm}$; upper part of thin unit is mainly coarse Sst, very poorly sorted; very coarse Sst 1 granule laminae; $(+)$ mm-thick laminae of coarse Sst, CU; (+) load casts. Heterolithic strata consisting of $18-25 \mathrm{~cm}$-thick tabular strata characterized by crudely stratified, low-angle planar-stratified, medium- to fine-grained sandstone, horizontal lamination and ripple cross-lamination, rippled at base, horizontal at top; rippled top erosional surface; finning-upward to silty mudstone alternated with millimetres to a few centimetres-thick laminated mudstones. The sandstone lenses dip outwards the main channel deposits. Soft-sediment deformation features characterized by pseudo-nodules which present typical ductile deformation including folding and boudinage. Clastic dykes characterized by coarse-grained sandstone emplaced vertically, both downwards and upwards, in the mudstone. 10-30 cm thick, brownish coarse-grained sandstones with well-rounded granules and pebbles presenting planar cross-stratification in sets or cosets. It coarsens upwards from sandstone at the base, then granules and finally lag of pebbles at the top. These sandstones commonly present mm- to a few cm-thick lamina of mudstone. Intraformational mudclasts are common with dimensions of up to $20 \mathrm{~cm} \times 2 \mathrm{~cm}$ dimensions. These facies commonly pinch-out and coarsens laterally to thin layers of well-sorted granules. Tool-like marks are commonly observed at the set base. Up to $25 \mathrm{~cm}$-thick reddish medium- to coarse-grained sandstones presenting horizontally bedded stratification and asymmetrical ripples organized in lenticular geometry which pinch out laterally.

Internally bedded, $10-30 \mathrm{~cm}$-thick mudstone with laminae $1-5 \mathrm{~mm}$ to $1 \mathrm{~cm}$ of very poorly sorted coarse-grained sandstone and granules, and also scattered blobs and balls. Apparently CU to next unit. Fine-grained sandstone, horizontal lamination and ripple cross-lamination; $3-20 \mathrm{~cm}$; rippled at base, horizontal at top; rippled top erosional surface; finning-upward to silty mudstone; pinches out laterally.
Point bar deposits related to the apex of such fluvial form. Granule and pebbles accumulation indicates avalanching of such deposits due to relatively steep dip.

Low-energy flow periods and possible flow cessation during which the observed mudstone drapes were preserved.

Settling out of fine-grained sediments during late stages of floods. Sandstone lenses are interpreted as the result of unconfined flow during early stages of flooding.

May record levee deposits or unconfined flow deposition during flood events.

Their origin is potentially related to differential compaction and/or sudden sediment load following crevasse splay deposits in floodplain setting.

Unconfined flow originated from river-bank rupture and the influx of a current stream over floodplain deposits, similar to small-scale crevasse splay deposits. Mudstone lenses indicate pause between splay re-activation.

Early phases of unconfined flow over floodplain deposits during flood events.

Soft sediment deformation due to burial pressure and differential compaction between mudstone and sandstone.

Unconfined flow deposition on floodplain during early flood stages. 
Table 2

Main architectural elements.

\begin{tabular}{|c|c|c|}
\hline Architectural elements & Description & Interpretation \\
\hline \multicolumn{3}{|l|}{ Channel deposits } \\
\hline DA & $\begin{array}{l}\text { Planar-stratified sandstones organized in cosets presenting planar } \\
\text { lower bounding surface which dips averagely in the same direction as } \\
\text { mean palaeoflow obtained from the internal cross stratification. Cosets } \\
\text { may be separated by thin mud drapes. Such forms are up to } 2 \mathrm{~m} \text { thick } \\
\text { and several metres wide. }\end{array}$ & Downstream accretion. Bar accretion during peak flow. \\
\hline SB & $\begin{array}{l}\text { Multi-story, multi-lateral sandstone bodies with laterally accreting } \\
\text { sets and cosets, and scouring sets. The external geometry of such } \\
\text { forms is characterized by tabular forms presenting undulating surfaces } \\
\text { (Fig. } 3 G \text { ) commonly eroding floodplain fine-grained sediments. } \\
\text { Scouring features filled by cosets of trough-stratified sandstones is } \\
\text { locally present. }\end{array}$ & $\begin{array}{l}\text { Sandy-bedforms. Subaqueous dunes and low } \\
\text { amplitude bars deposition in channel. }\end{array}$ \\
\hline PB1 & $\begin{array}{l}\text { Inclined heterolithic strata presenting downstream accretion: } \\
\mathrm{cm} \text {-thick, crudely-stratified fine- to medium-grained sandstones } \\
\text { alternated with } \mathrm{mm} \text { - to } \mathrm{cm} \text {-thick clayey siltstone, in coarse-to-fine } \\
\text { couplets separated by inclined surfaces. Thickness vary from } 60 \mathrm{~cm} \text { to } \\
2.0 \mathrm{~m} \text {. The relationship between lower bounding surface and internal } \\
\text { strata is characterized by parallel dip directions. }\end{array}$ & $\begin{array}{l}\text { Point bar 1: deposition on downstream part of point } \\
\text { bars as the result of fluctuations in flow discharge. }\end{array}$ \\
\hline PB2 & $\begin{array}{l}\text { Wedge-shaped lenticular bodies of coarse-grained sandstone with } \\
\text { convex-upward upper bounding surface, accreting laterally to mean } \\
\text { palaeocurrent direction, which is more varied than PB1. Internal } \\
\text { stratification dips at right angles to main bounding surfaces; internal } \\
\text { cossets may be separated by mud drape; these sandstone bodies } \\
\text { pinch-out both upwardly and downwardly. Lateral accretion } \\
\text { macroforms. }\end{array}$ & $\begin{array}{l}\text { Point bar 2: deposition on apex of point bars recording } \\
\text { lateral accretion. }\end{array}$ \\
\hline UA & $\begin{array}{l}\text { Lenticular bodies composed of series of cosets characterized by planar } \\
\text { and trough cross-stratified sandstone with lower bounding-surface } \\
\text { that dips averagely in the opposite direction of cross-sets. The latter } \\
\text { typically dips in the opposite direction of the surrounding cross-sets } \\
\text { related to other fluvial forms. Intraformational mudclasts are common. }\end{array}$ & $\begin{array}{l}\text { Upstream accretion: deposition on upstream margin of } \\
\text { bars as a result of upstream flow caused by flow } \\
\text { separation. }\end{array}$ \\
\hline LS & $\begin{array}{l}\text { Tabular-geometry sandstone bodies characterized by internal } \\
\text { stratification of low-angle cross-stratification to horizontal } \\
\text { stratification. }\end{array}$ & $\begin{array}{l}\text { Laminated sandstone sheets. Such deposits record } \\
\text { deposition during waning flow stages in shallow } \\
\text { streams or during peak discharges. }\end{array}$ \\
\hline SF & $\begin{array}{l}\text { Sandstone bodies characterized by cosets of trough cross-stratified, } \\
\text { coarse-grained to pebbly sandstones presenting concave-up bounding } \\
\text { surface and relatively flat upper bounding-surface. }\end{array}$ & $\begin{array}{l}\text { Scour fill. Deposition in small secondary channels } \\
\text { during early stages of avulsion. }\end{array}$ \\
\hline \multicolumn{3}{|l|}{ Floodplain deposits } \\
\hline OF & $\begin{array}{l}\text { Horizontally laminated siltstone and mudstone organized in tabular } \\
\text { bodies. In some of the studied examples it pinches-out laterally. Such } \\
\text { forms are up to } 2 \mathrm{~m} \text { thick and several tens of metres wides. }\end{array}$ & $\begin{array}{l}\text { Overbank fines. Overbank fines deposited in long lived } \\
\text { floodplains. }\end{array}$ \\
\hline CS & $\begin{array}{l}\text { Lenticular bodies comprising medium- to coarse-grained sandstone } \\
\text { and granules with medium- to low-angle planar cross stratification. } \\
\text { Lower bounding surface is usually erosive and commonly irregular, } \\
\text { sometimes presenting lag of pebbles and tool marks. Convex-upward } \\
\text { to slightly planar upper bounding surfaces. }\end{array}$ & Crevasse-splays. \\
\hline $\mathrm{CC}$ & $\begin{array}{l}\text { Lenticular bodies of concave-upward lower bounding surface and flat } \\
\text { upper bounding surfaces. They occur laterally related or above } \\
\text { crevasse-splay forms. Dimensions are of } 15-30 \mathrm{~cm} \text { thick, } 30 \mathrm{~cm} \text { to a } \\
\text { couple of metres wide. }\end{array}$ & Crevasse channels. \\
\hline LV & $\begin{array}{l}\text { Tabular-shaped lenses of well-sorted, medium- to coarse-grained } \\
\text { sandstones in laterally extensive bodies } 5-10 \mathrm{~cm} \text { thick (check) overlain } \\
\text { by } \mathrm{cm} \text {-thick, tabular bodies of mudstone and siltstone. }\end{array}$ & $\begin{array}{l}\text { Channel levees, characterized by deposition of } \\
\text { unconfined-flow deposits related to channel-bank } \\
\text { deposition during flood events. }\end{array}$ \\
\hline$A C$ & $\begin{array}{l}\text { Lenticular bodies characterized by concave-up lower bounding surface } \\
\text { and truncated on top, filled by laminated mudstone. }\end{array}$ & Abandoned channel deposits. \\
\hline
\end{tabular}

for the Allt na Béiste Member, proposed by Stewart (2002), based on a number of evidences, including: palaeocurrent directions (not bimodal), bedform types (no symmetrical ripples, predominance of cross-stratification), well-rounded pebbles, and continuous gradation to the typical Applecross Formation lithofacies.

Two distinct facies associations represent different depositional elements: (1) sandstone-dominated facies characterized by crossstratified sandstones organized in laterally extensive sandbodies and inclined heterolithic bodies, interpreted as channel complexes; and (2) fine-grained facies organized in complex and varied depositional architectures, interpreted as floodplain units. These distinct depositional elements are unique to the Allt na Béiste Member; in the rest of the Applecross Formation the distinction between channel and floodplain deposits is not straightforward, due to intense amalgamation of channel deposits, paucity of preserved fine-grained sediments, and reworking of floodplain deposits.

\subsection{Sandstone-dominated facies association: channel complexes}

\subsubsection{Sedimentary facies}

These intervals are characterized by well-cemented, mediumto coarse-grained arkosic sandstones and pebbly sandstones that are reddish-brown when weathered and dark red to pale grey when fresh, with subordinate $\mathrm{cm}$-thick siltstone lenses and $\mathrm{mm}$ to $\mathrm{cm}$-thick red and grey shale partings (Table 1). The sandstones contain trough and planar cross-stratification with some synsedimentary soft-sediment deformation (Fig. 3A), although not on the frequency or scale typical of most of the Applecross Formation (e.g. Selley, 1965; Owen, 1995, 1996; Owen and Santos, 2014). Finegrained sandstone and silty mudstone occur as $\mathrm{cm}$ - to dm-thick lenses, commonly preserving depositional forms in underlying beds (Fig. 3A and B). Extraformational granules and pebbles are well-rounded and polymictic. Intraformational mudclasts $\mathrm{mm}$ to 


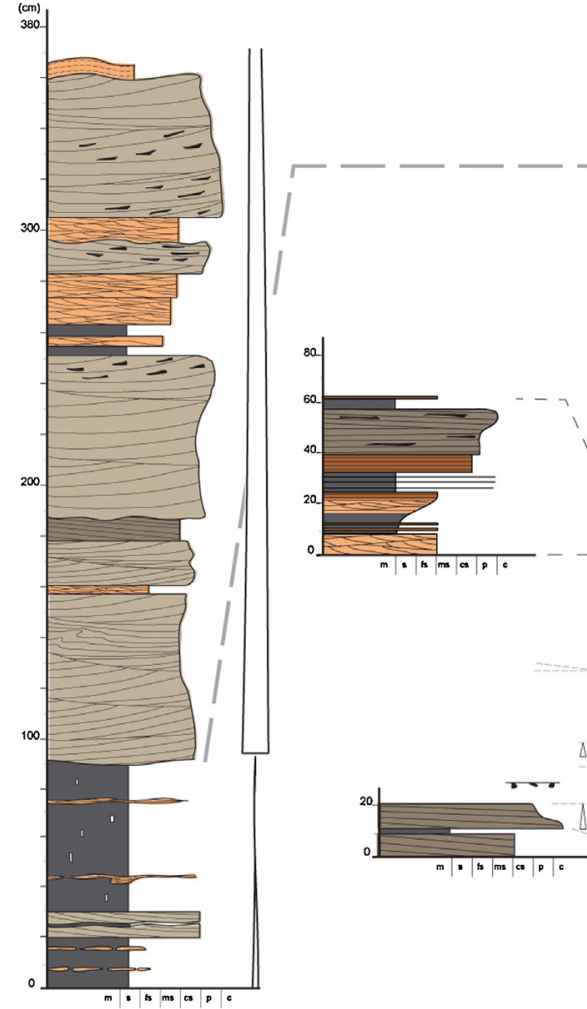

LEGEND

Planar cross-stratification

Trough cross-straticication

Liquidized stratification

Horizontal to low-angle stratification

Cross-lamination

Mud

Intraformational mudclasts

Blobs and balls

I I Sandstone dykes

Fining-upwards cyles

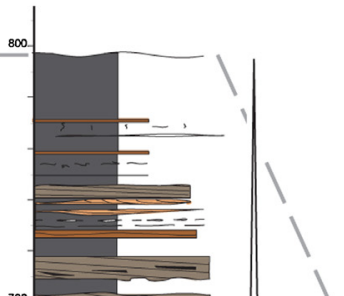

700
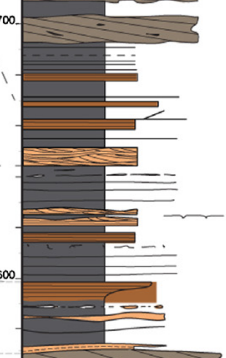

$+\frac{1}{2-12}$

1
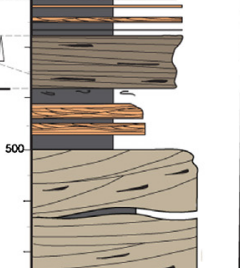

$-$
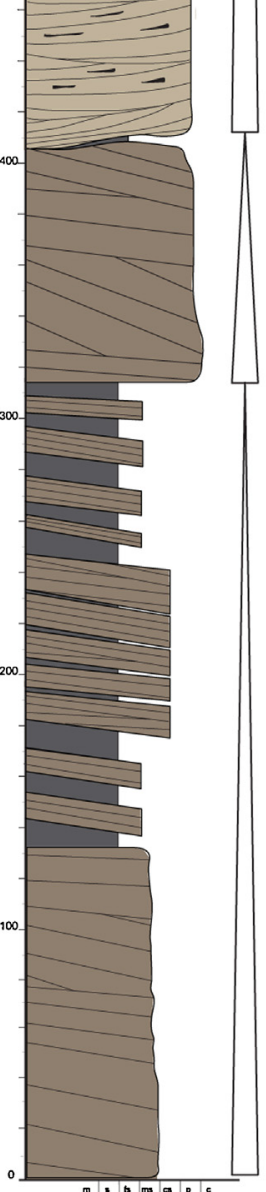

sect.

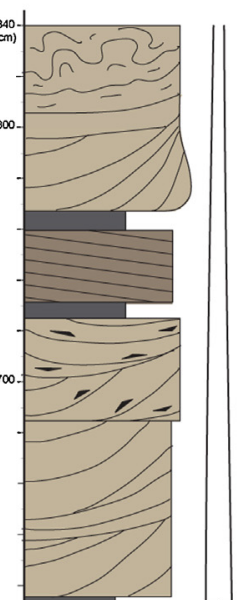

$\infty$

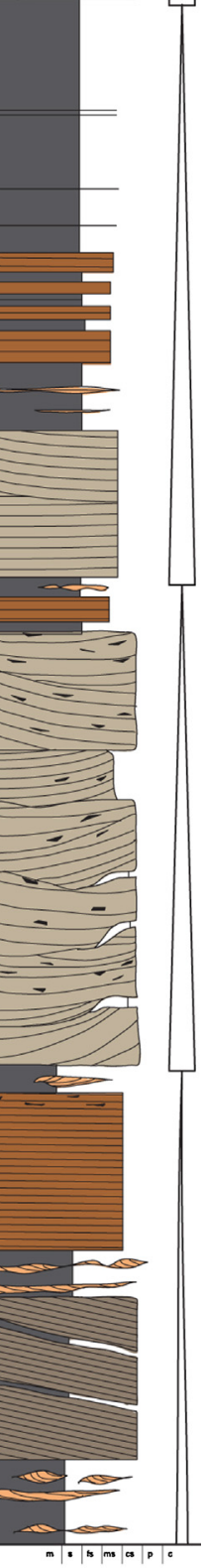

Fig. 2. Sedimentary logs of the Allt na Béiste Member in its type area in the coastal cliffs of Diabaig (see location in Fig. 1). Distance between measured sections is 10 m. 

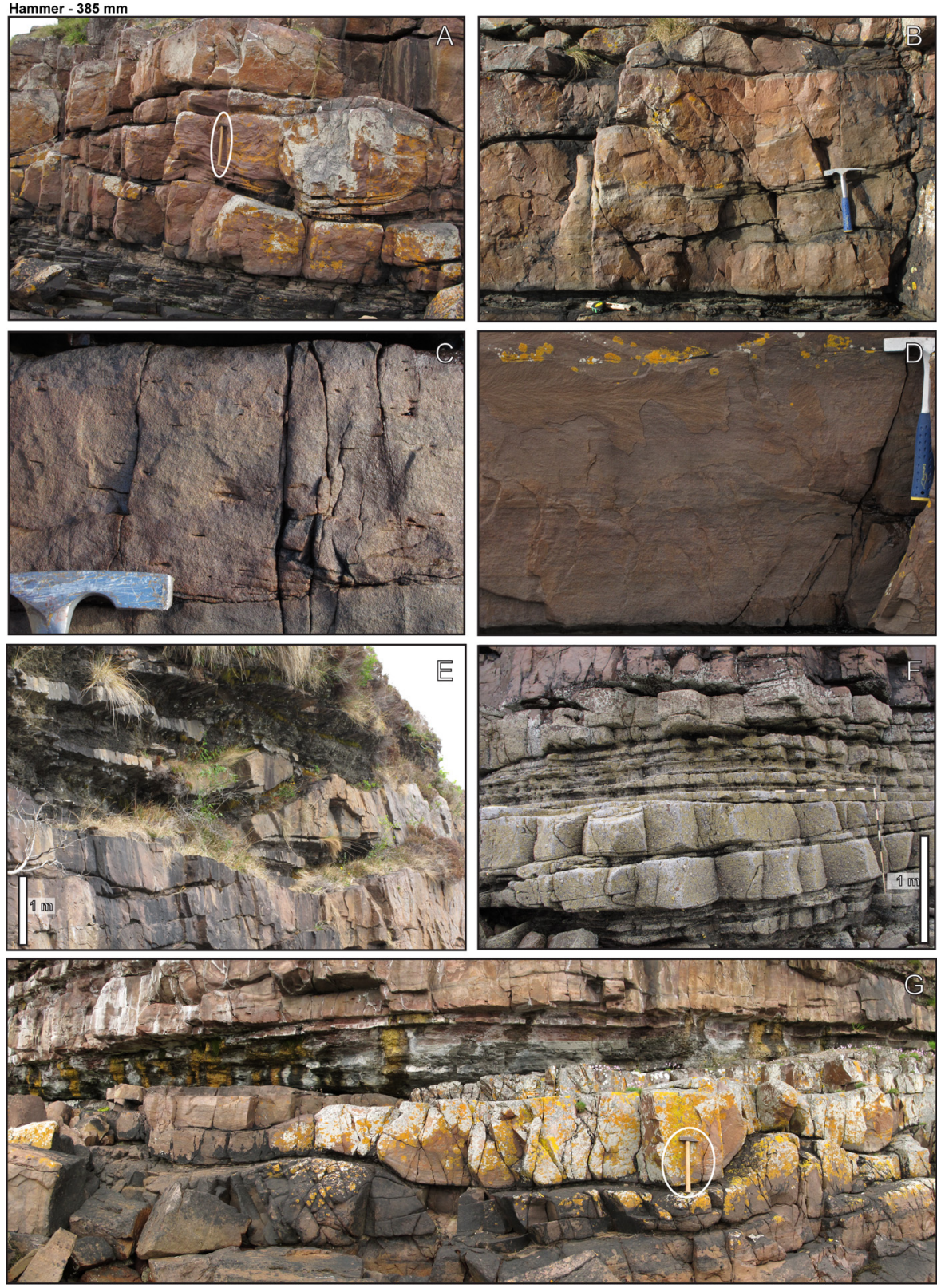

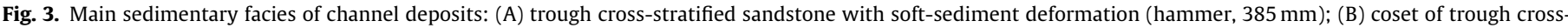

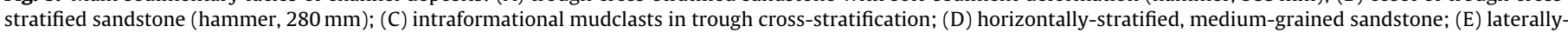

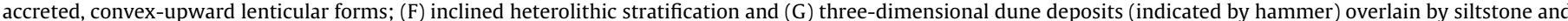
silty-mudstone.

$\mathrm{cm}$ long are concentrated at the bases of many sets (Fig. 3C). Horizontal and low-angle cross-stratification occur in fine- to coarse-grained sandstones (Fig. 3D). Fine-grained sediments comprise laminated and cross-laminated fine-grained sandstone to silty mudstone. Lenticular heterolithic intervals (Fig. 3E) are characterized by $\mathrm{cm}$-thick couplets of fine- to coarse-grained sandstone intercalated with silty mudstone, which pinch out laterally (Fig. 3F). Although most set bounding surfaces are erosional, some preserve the shape of underlying bedforms, from which they are usually separated by a thin layer of finer-grained sediment that commonly weathers out (Fig. 3G).

\subsubsection{Depositional architecture}

Sandstone-dominated facies associations are organized into laterally-extensive lenticular and tabular bodies decimetres to metres thick and metres to $10 \mathrm{~s}$ of metres wide. The geometry of basal bounding surfaces is varied, including wavy, dipping, concave-upward, convex-upward, and horizontal planar surfaces (Fig. 4). Fine-grained drapes (siltstone and silty-mudstone) a few millimetres thick and tens of centimetres wide with lenticular and wavy geometry cover bedforms in underlying units. Concave-upward scour geometries are typically filled by trough cross-stratified sandstones and intraformational conglomerates. Trough cross-stratified sandstones and pebbly sandstones are commonly organized in multi-storey, multi-lateral sandstone bodies with wavy geometry as a result of erosion of the underlying beds (Fig. 5).

Heterolithic strata occur in lenticular bodies up to $2 \mathrm{~m}$ thick (Fig. 4) characterized by inclined beds comprising coarse-to-fine couplets (cf. Thomas et al., 1987) in which sandstone cosets are characterized by low-angle planar cross-stratification (Fig. 6). These forms commonly pinch out laterally over $4-5 \mathrm{~m}$ (Fig. 7) 


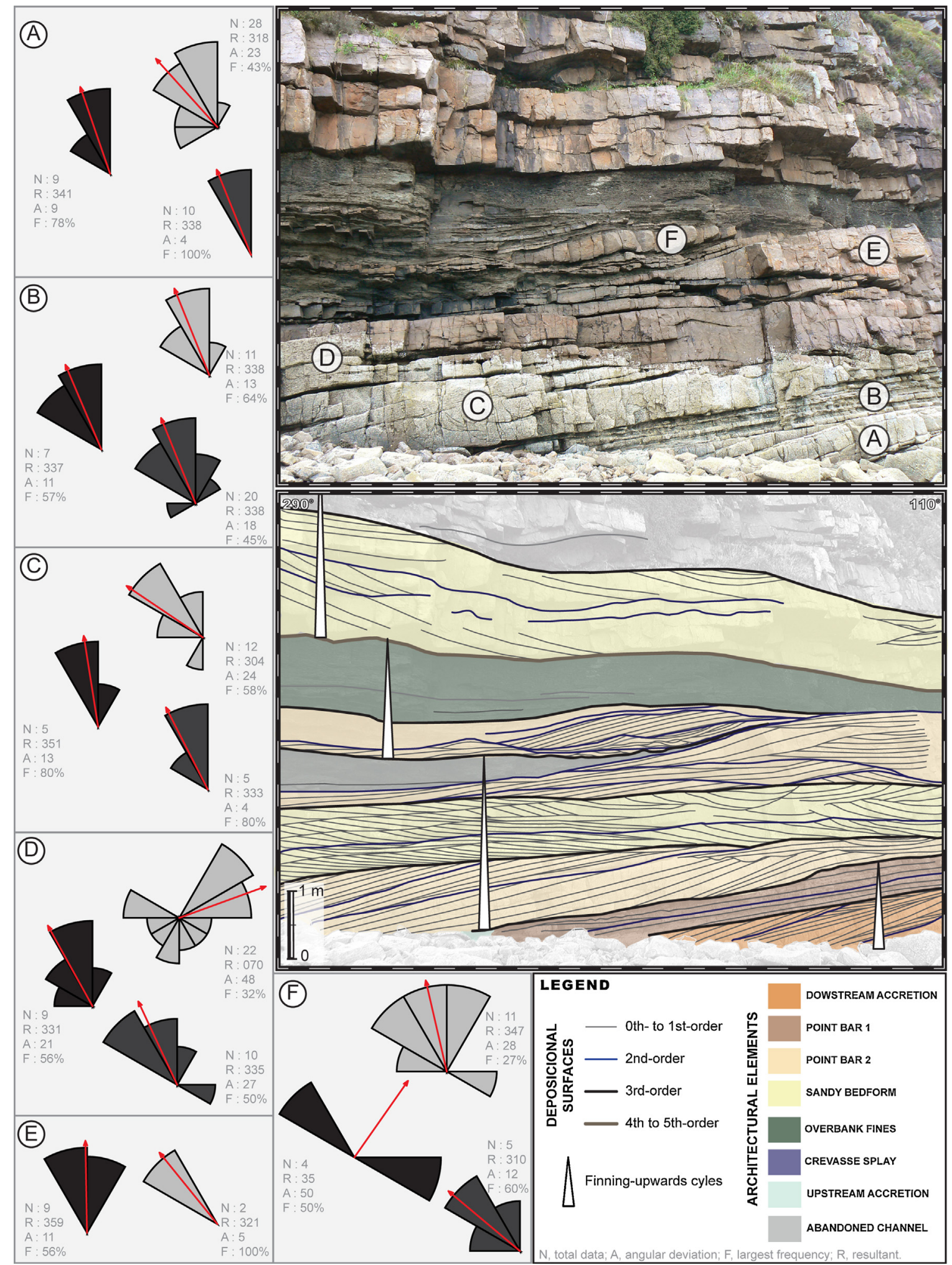

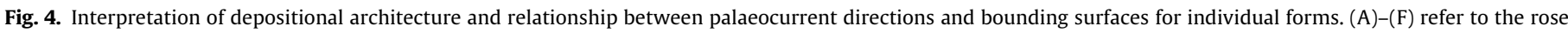

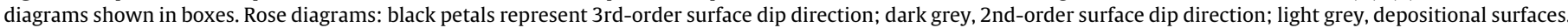

and their internal structures indicate palaeoflow parallel to the dip direction of the bed. Associations of planar cross-stratified sandstones with trough cross-stratified sandstones are organized in various forms, including: (1) wedge-shaped bodies with convex-upward upper bounding surfaces and internal palaeoflow indicators dipping at oblique to high angles $\left(>30^{\circ}\right)$ relative to the flat lower bounding surfaces; (2) lenticular bodies with palaeoflow indicators dipping in the opposite direction to dip of the lower bounding surface; and (3) bodies with concave-upward lower bounding surfaces and relatively flat upper bounding surfaces. Cosets of low-angle planar cross-stratification are typically organized into tabular geometries. 


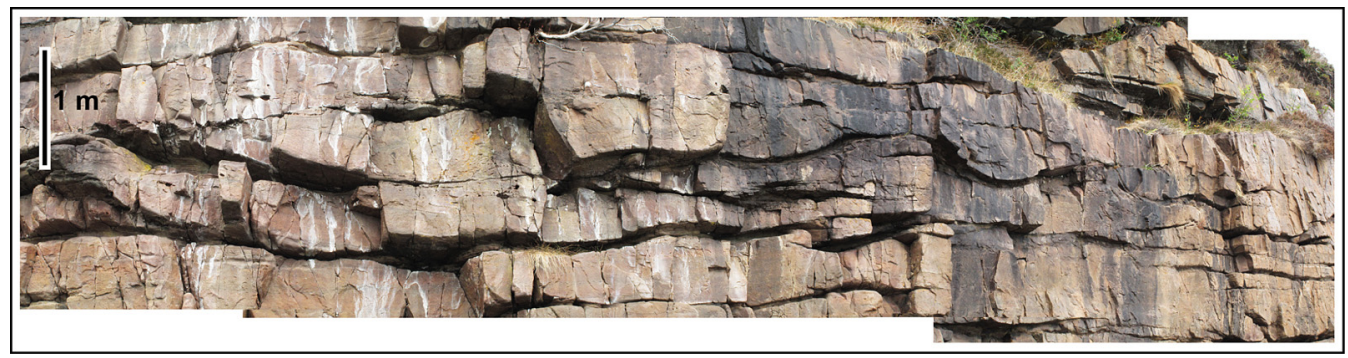

Fig. 5. Multi-storey, multi-lateral sets of sandbodies (lower part of the picture) and laterally-accreting point bar (upper right of the picture).
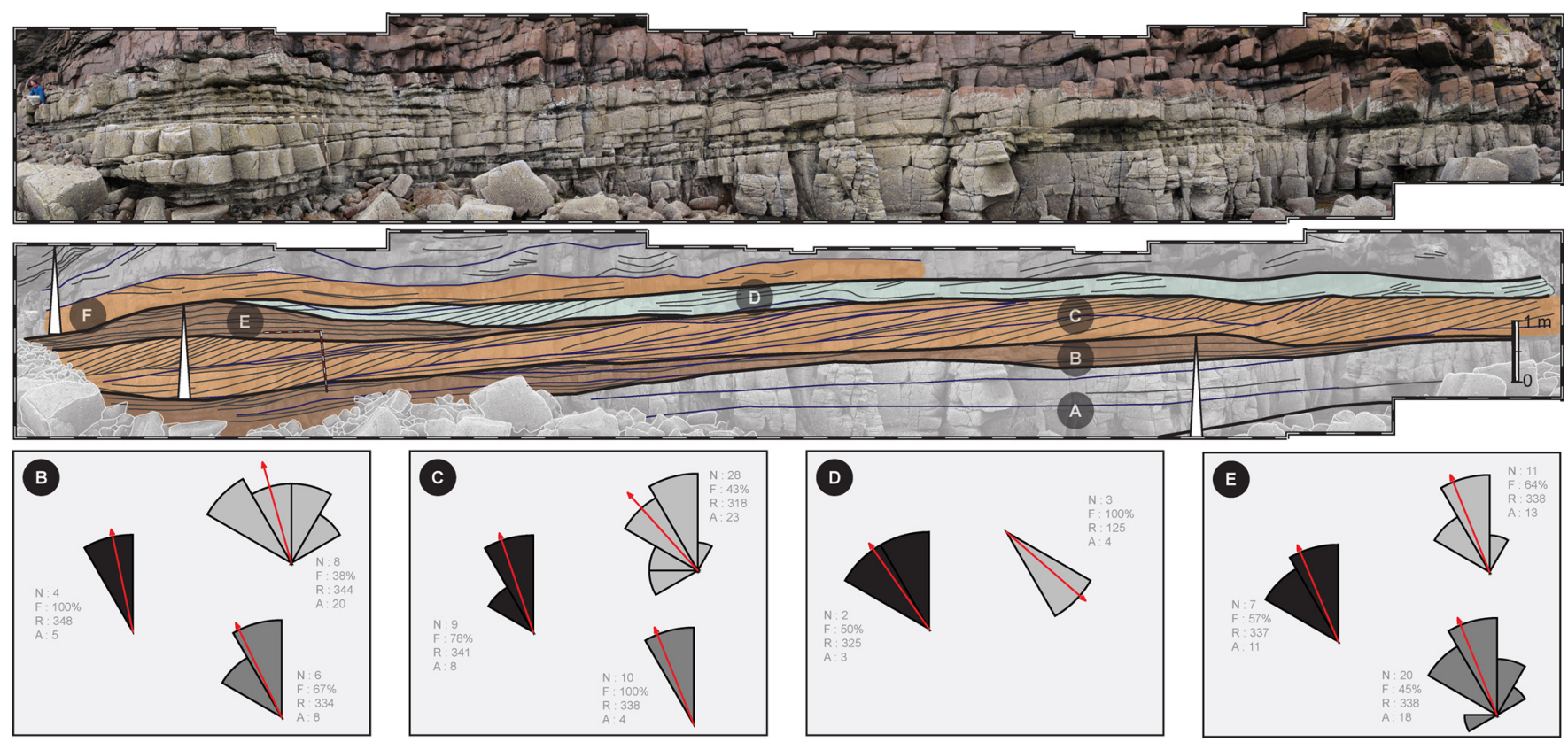

Fig. 6. Inclined heterolithic strata in channel deposits. (B)-(E) refer to the rose diagrams shown in boxes. Legend as Fig. 4.

\subsubsection{Interpretation}

These sandstone-dominated intervals are interpreted to represent channel complexes. Their internal architecture and the dip data indicate a variety of channel geometries. The sandstonedominated intervals therefore record a range of channel forms, including evidence of laterally-accreted channels, which are typically related to meandering-channel planforms. Architectural elements identified in the channel deposits include (Table 2): point bars, downstream accretion, upstream accretion, sandy bedforms, laminated sandstone sheets, and scour-fill. Abundant intraformational mudclasts provide evidence of intense reworking of fine-grained sediments deposited during periods of quiet conditions, possibly on mud flats, indicating variable flow regimes and/or floodplain reworking. Inclined heterolithic strata with palaeoflow indicators parallel to the dip directions of lower bounding surfaces are interpreted as point-bar deposits (PB1) that accumulated in the downstream part of the bar, with intercalation between traction and suspension deposition as a result of fluctuations in flow discharge (Fig. 4). Planar cross-stratified sandstones with palaeoflow indicators dipping at oblique angles $\left(\sim 45^{\circ}\right)$ to the dip direction of inclined planar lower bounding surfaces, and convex-upward upper bounding surfaces are interpreted as lateralaccretion deposits recording deposition on the apex of point bars (PB2). Multi-storey, multi-lateral sandstone bodies with palaeoflow indicators that dip at right angles to the dip of wavy lower bounding surfaces, convex-upward upper bounding surfaces and

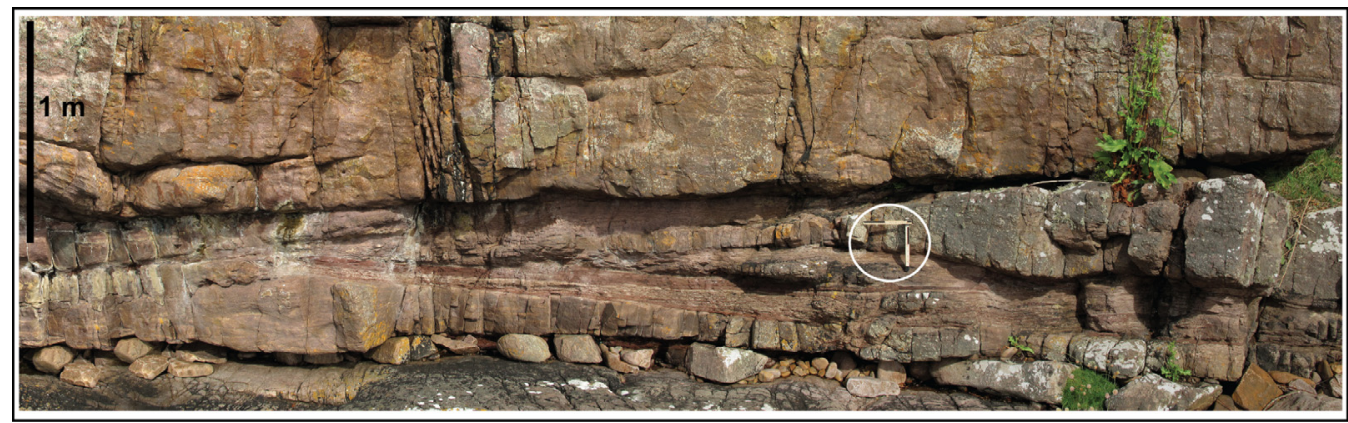

Fig. 7. Laterally-accreted channel deposits pinching out laterally. Horizontal and vertical scale bar (white circle) is $20 \mathrm{~cm}$ long. 
abundant intraformational clasts are interpreted as sandy bedforms (SB), representing in-channel deposition of 3D dunes with transport at right angles $\left(\sim 90^{\circ}\right)$ to the lower bounding surface dip of the underlying point bar. Intervals with lower bounding surfaces that dip in the same direction as palaeoflow indicators in surrounding fluvial forms, but in the opposite direction to the internal palaeoflow indicators are interpreted as upstream accretion (UA) forms deposited on the upstream margins of bars as a result of upstream flow. Cosets of planar cross-stratified sandstones characterized by lower bounding surfaces and 2nd- and 3rd-order surfaces that dip concordantly with the internal palaeoflow indicators are interpreted as downstream-accretion macroforms (DA), recording bar accretion during peak flow (Fig. 6). Tabular sandstone bodies composed of medium- to coarse-grained sandstones with low-angle to horizontal stratification represent laminated sandstone sheets (LS), recording deposition during waning flow stages in shallow streams or during peak discharges.

\subsection{Fine-grained facies association: floodplain units}

\subsubsection{Sedimentary facies}

A wide range of mudstone-dominated and heterolithic facies are present (Table 1 ). Silty mudstone, and laminated and crosslaminated fine-grained sandstone (Fig. 8A) alternate with cm-thick lenses of coarser sediment. Other facies are characterized by $\mathrm{m}$ thick laminated and massive units of mudstone (Fig. 8B) that are red to dark grey when fresh and pale red when weathered. Coarser-grained lenses include beds of sandstone or granules with horizontal lamination, fine-grained sandstones with asymmetricto wavy climbing-ripple cross-lamination (Fig. 8C and D), fineto coarse-grained sandstone with horizontal to low-angle stratification, and coarse-grained sandstone and granulestone with planar cross-stratification (Fig. 8E and F). These commonly include intraformational mudclasts up to $20 \mathrm{~cm}$ long (Fig. 8E) which are darker in colour than the surrounding mudstones. Some lenses of poorly-stratified to massive granule to pebble conglomerate are only as thick as the clasts they contain. Other lenses of pebbly sandstone contain soft-sediment deformation ranging from smooth synclines with wavelengths of a few centimetres (Fig. 8G) to complete disruption into pseudonodules (Fig. 8H). Some of the horizontally bedded sandstones dip gently in the opposite direction to laterally-related sandstone (channel) deposits (Fig. 9). Clastic dykes of medium- to coarse-grained sandstone are common and are up to a few centimetres thick and wide. Some originate in the upper regions of lenticular sandstone bodies and some are tightly folded. Other dykes are just a few millimetres wide and filled by granules.

\subsubsection{Depositional architecture}

Fine-grained facies are organized into a range of depositional forms. Some bodies of heterolithic strata are tabular over metres to tens of metres, with flat to wavy lower bounding surfaces and convex upper bounding surfaces. They pinch out rapidly at their margins. Others incorporate beds that dip at a high angle away from laterally-equivalent sandstone (channel) bodies (Fig. 9). Mudstonefilled lenticular bodies are characterized by concave-upward lower bounding surfaces and flat upper bounding surfaces. Some massive mudstone units are characterized by irregular, wavy lower bounding surfaces and relatively flat upper bounding surfaces (Fig. 10). These are laterally related to point bars of channel deposits, while other mudstone-filled bodies are tabular with very thin lenses of sandstone and granulestone. Some planar cross-stratified sandstone lenses also occur within mudstone bodies, and pinch out laterally at both ends, being characterized by flat lower bounding surfaces and convex-upward upper bounding surfaces (Fig. 9), commonly with a pebble lag and tool marks at their base. Other cross-stratified sandstone lenses are characterized by concaveupward lower bounding surfaces and flat upper bounding surfaces.

\subsubsection{Interpretation}

These heterolithic bodies represent floodplain deposits (Table 2). Tabular bodies of mostly muddy heterolithic strata (Fig. 10) are interpreted as overbank fines which accumulated in long-lived floodplains (OF). Heterolithic beds that dip away from laterally-equivalent sandstone (channel) bodies (Fig. 9) are interpreted as possible channel levées (LV), similar to the ones described in Miall (1979), but smaller in scale, and these are different from those described in younger successions of the Applecross Formation (Ielpi and Ghinassi, 2015). Planar cross-stratified sandstone lenses in mudstone that pinch out laterally, with flat lower bounding surfaces represent crevasse-splay deposits (CS). Intraformational mudclasts indicate re-working of previously deposited overbank fines. Mudstone-filled lenticular bodies with concave-upward lower bounding surfaces and flat upper bounding surfaces which are associated with CS forms are interpreted as crevasse channels (CC). Finally, mudstone-filled lenticular bodies with concave-upward lower bounding surfaces and which are truncated upwards are interpreted as abandoned channels (AC). Tightly folded dykes indicate compaction of the enclosing fine-grained sediment after dyke injection.

\subsection{Palaeocurrents}

Orientations of 347 surfaces were measured, including 194 palaeocurrent readings from cross-sets and 153 measurements of higher-order (1st- to 4th-order) surfaces (set and coset bounding surfaces and major erosional surfaces). The data are plotted as rose diagrams with an equal-area frequency scale (Nemec, 1988; Baas, 2000; Fig. 11). Palaeoflow indicators show mean transport towards $334^{\circ}$ (angular deviation $39^{\circ}$, largest frequency 26\%). Higher-order surfaces show mean dip towards $336^{\circ}$ (angular deviation $30^{\circ}$, largest frequency 46\%). Relationships between depositional surfaces and higher-order surfaces (Figs. 4, 6 and 9) are characterized by deviations of up to $99^{\circ}$ in sandy bedforms and up to $160^{\circ}$ in upstream accretion forms, both clockwise and anticlockwise. Sandy bedforms present the largest observed range of directions, with angular deviations up to $48^{\circ}$ and largest frequency of $32 \%$ (Fig. 4). Crevasse splays present deviation of palaeocurrent in relation to higher-order surfaces, which are concordant with the overall sediment transport direction, of up $81^{\circ}$. Sediment transport indicated by 0 th-order surfaces varies from $304^{\circ}$ to $070^{\circ}$ in Fig. 4 and $318^{\circ}$ to $125^{\circ}$ in Fig. 6. Crevasse splay depositional transport is consistently to the west, and perpendicular to the overall sediment transport of the inchannel deposits. The mean transport to NNW $\left(335^{\circ}\right)$ contrasts with results from studies of successions higher in the Applecross Formation, which show mean transport to the SE (e.g. Nicholson, 1993; Stewart, 2002; Williams, 2001; Williams and Foden, 2011). This may reflect a contrast in sediment transport with the overlying successions of the Applecross Formation as a result of coeval channels flowing into Lewisian palaeovalleys before the establishment of the main fluvial system represented by the typical Applecross Formation.

\subsection{Sandstone dykes and fractures}

Sandstone-filled fissures and associated fractures are common in the fine-grained and heterolithic facies in Diabaig, near the type-section of the Allt na Béiste Member. Some sandstone-filled fissures are connected to an overlying sandstone bed (Fig. 12A) and may represent infilled desiccation cracks. Others are connected to underlying beds or are isolated within mudstone (Fig. 12B). Several are contorted by soft-sediment deformation. These varieties 

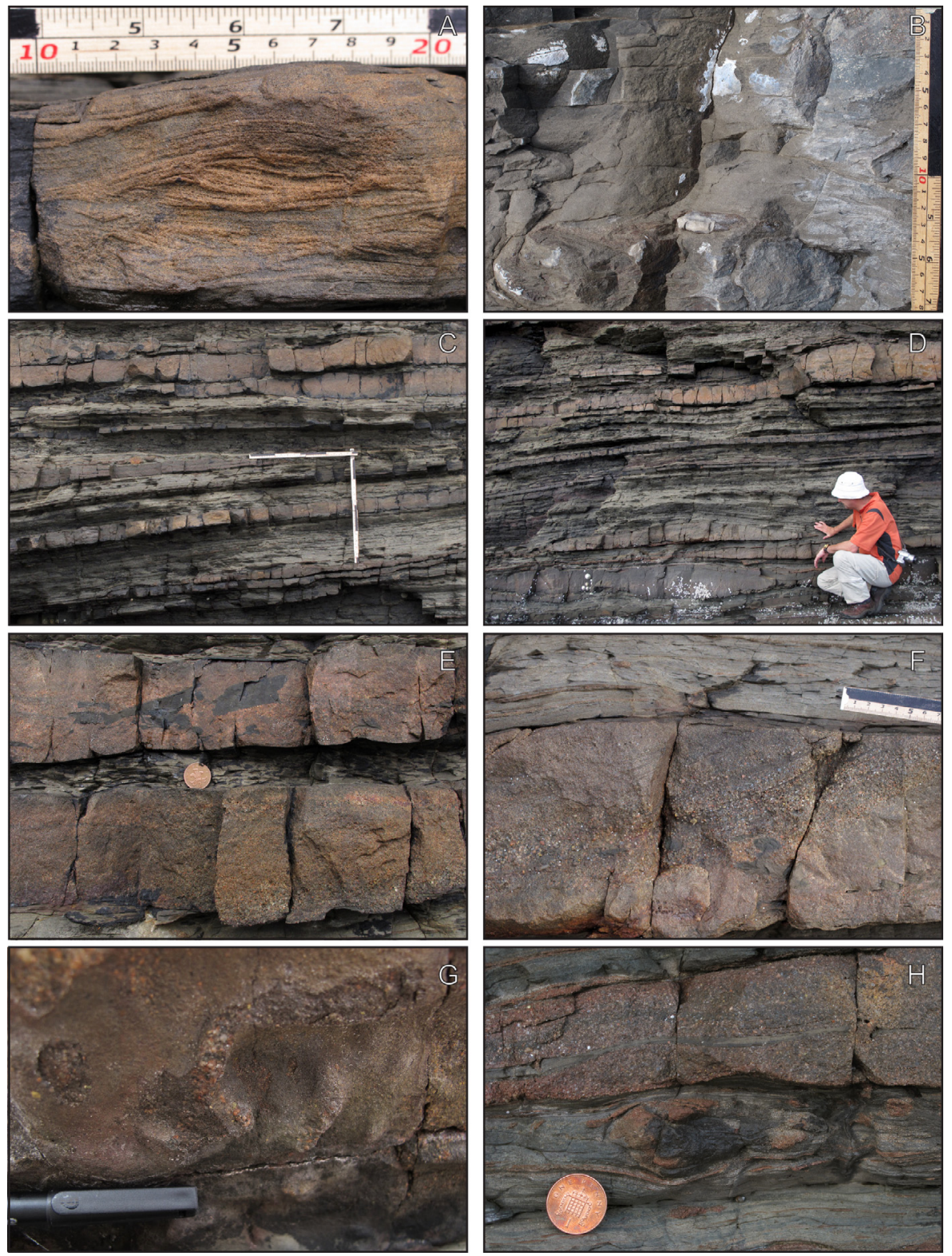

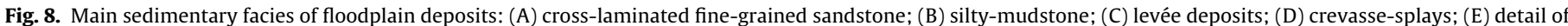

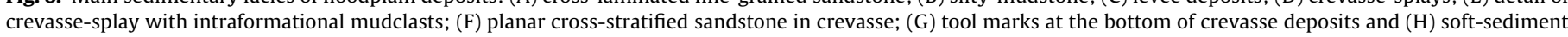
deformation: pseudonodules in mudstone.

are likely to represent sandstone dykes injected through the fluidization of water-saturated sediments (Lowe, 1975; Owen, 1996). Orientation data show a consistent NE-SW strike $\left(042^{\circ}-222^{\circ}\right.$; Fig. 9), similar to dykes described by Stewart (2002). This uniform trend indicates a NW-SE extensional palaeostress field shortly after deposition, most likely related to basin extension and, together with the palaeocurrent data, this is consistent with models of an extensional basin with a NE-SW axis, infilled by transverse alluvial systems (e.g. Williams, 2001). The injection features may indicate enhanced seismic activity associated with deposition of the Applecross Formation, culminating in the abundant large-scale soft-sediment deformation higher in the succession (e.g. Owen, 1996). Some of the observed dykes originated in underlying and overlying crevasse splays, while others seem to be unconnected with any particular sandstone body, being characterized as isolated features of sandstone between the mudstone. This is inferred after the structural analysis of fractures in the studied deposits: clastic dyke orientations are strongly concordant with joints, indicating that the deposits were well lithified before such brittle deformation occurred. Along the Diabaig shoreline, a prominent fault cutting through floodplain and channel deposits with displacement up to $30 \mathrm{~cm}$ and a strike oblique to the sandstone-filled fissures and fractures (Fig. 10) is interpreted as a later, tectonic feature. An alternative interpretation of these sandstone dykes is that they may reflect variable compaction of muds in the underlying Diabaig Formation leading to contrasting rates of local subsidence and promoting the development of lower-lying areas prone to the development of floodplain ponds.

\section{Discussion}

\subsection{Fluvial styles in the Allt na Béiste Member and their significance}

The Allt na Béiste Member records variable channel style, including both meandering planforms with coeval deposition of 


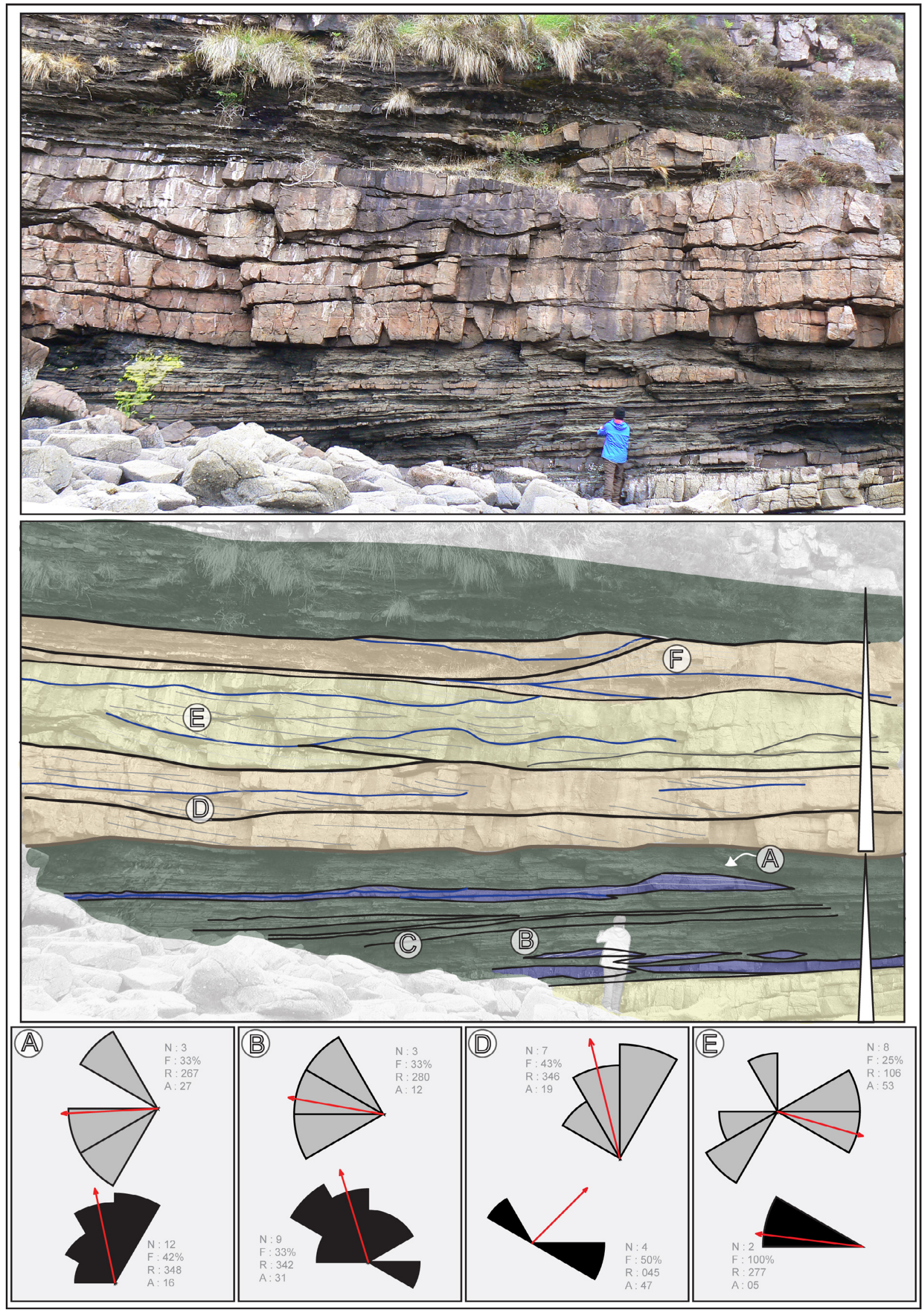

Fig. 9. Crevasse-splays in the Allt na Béiste Member and associated forms such as SB and PB2. (A)-(E) rose diagrams shown in boxes; legend as Fig. 4. (C) levée deposits and (F) point bar similar to the one depicted in Fig. 4. 


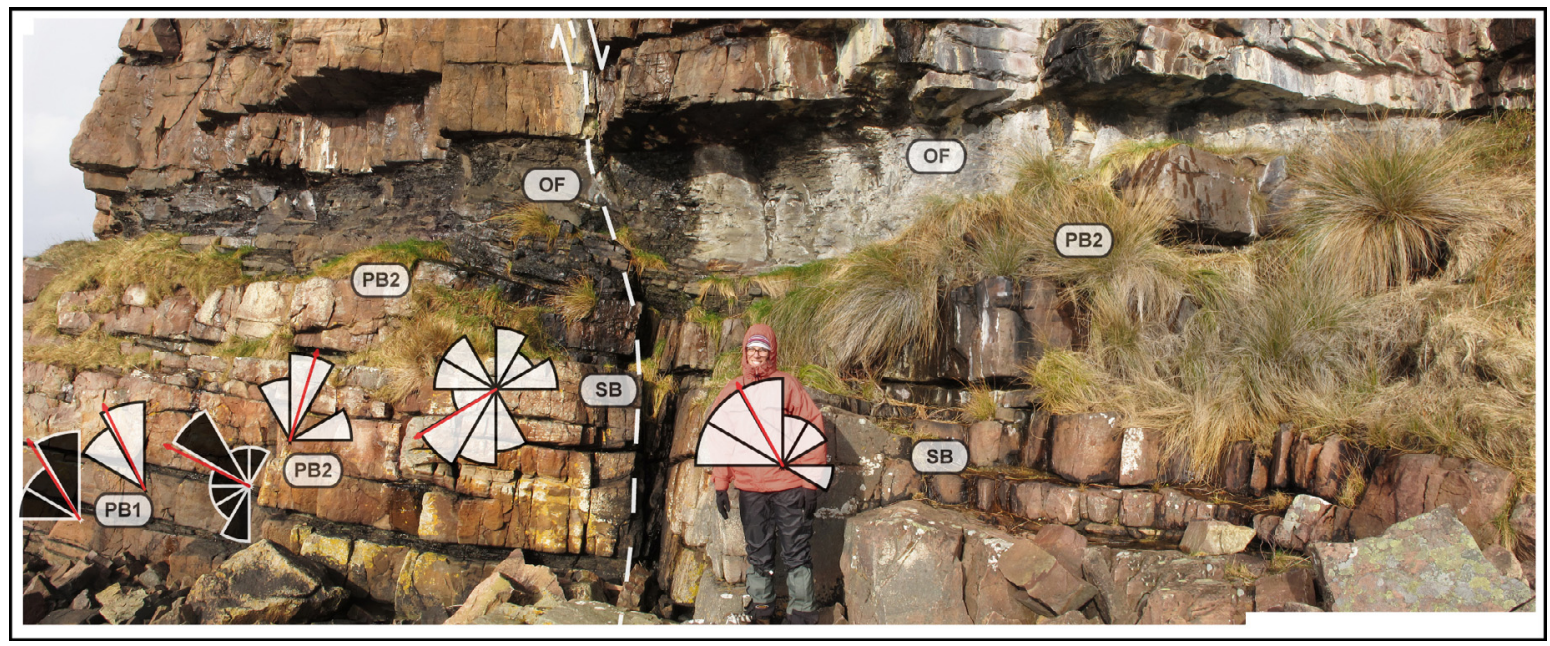

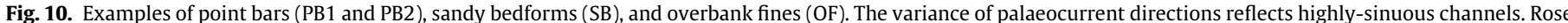

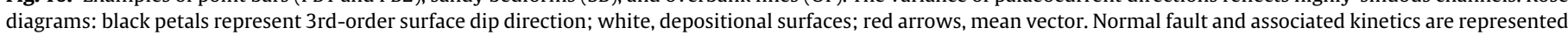
are represented in dashed white lines. Person as scale: $1.72 \mathrm{~m}$.

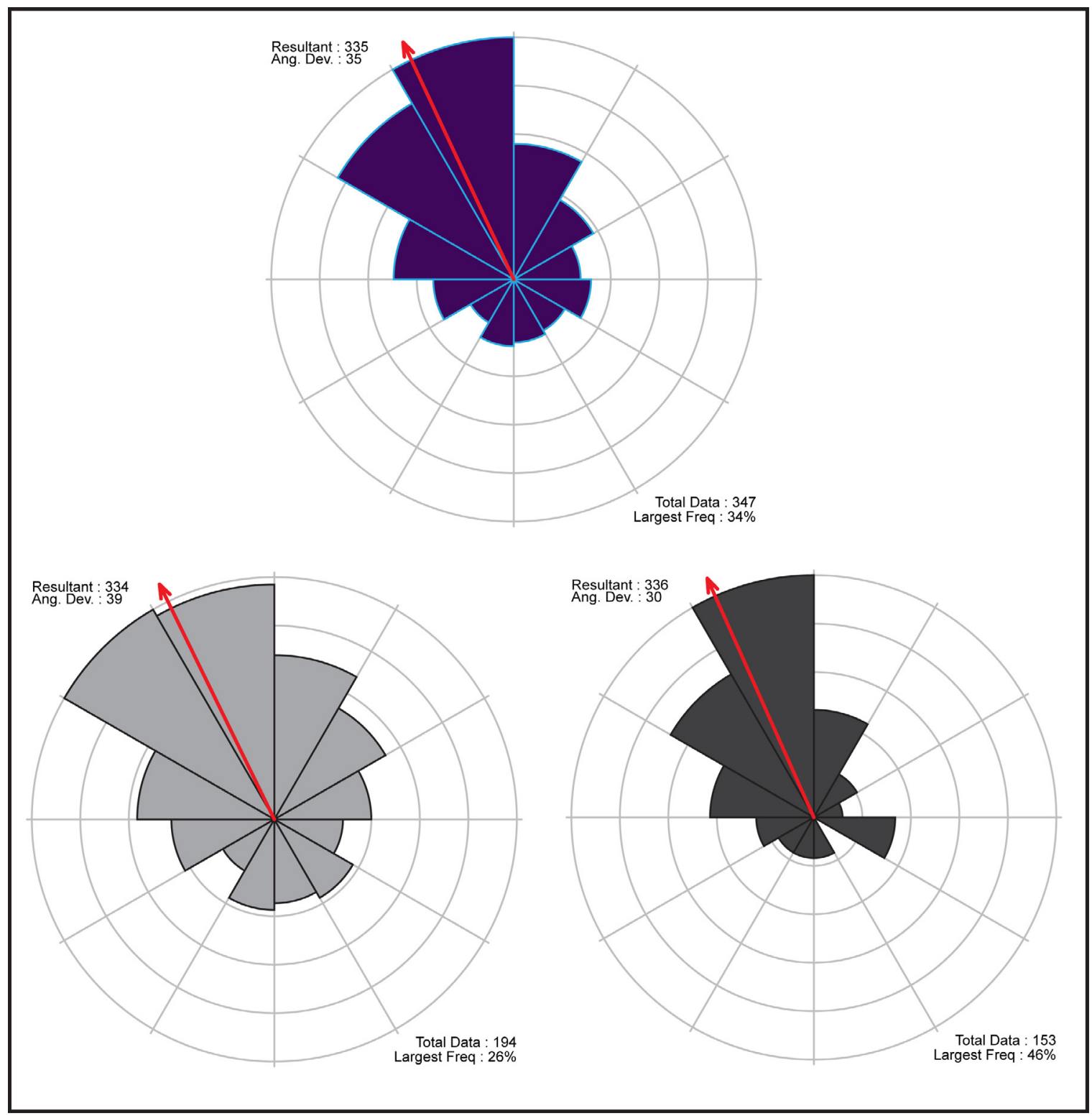

Fig. 11. Palaeocurrent data for the Allt na Béiste Member. Blue petals, all data; light grey, cross-set data; dark grey, main bounding surfaces. 


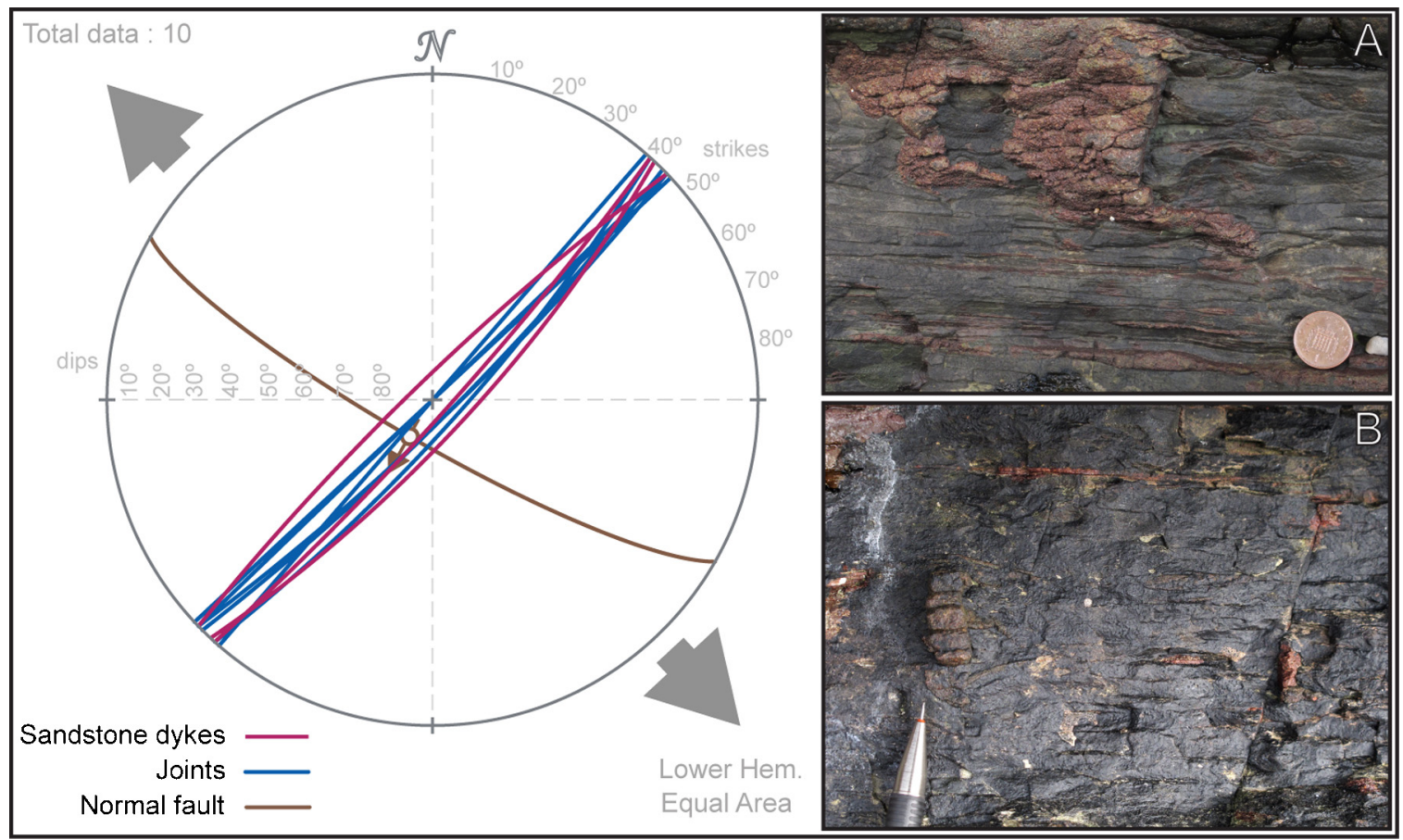

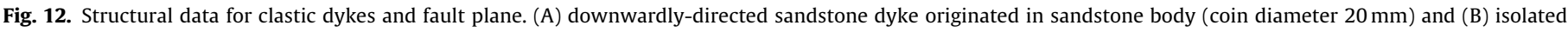
dykes in mudstone deposits (pencil metallic part is $20 \mathrm{~mm}$ ). Grey arrow represents main extensional stress field.

crevasse splays and crevasse channels (Fig. 9), and multi-storey, multi-lateral sets (Fig. 5). The identified architectural elements are summarized in Fig. 13. The laterally accreted units (Figs. 4 and 6) share many features with lateral accretion attributed to meandering sand-bed streams by Allen $(1963,1964)$ and Jackson (1978): heterolithic sand-mud stratification, cross-stratification dipping at oblique angles to basal bounding surfaces; fining-upward successions (Fig. 2), steep $\left(>20^{\circ}\right)$ point-bar slopes, and comparable thickness of coarse and fine intervals. Although river systems characterized by laterally accreting channel banks and regularly inundated floodplains were apparently rare during the Precambrian, the data from the Allt na Béiste Member indicate that meandering channels could develop if river banks could be stabilized by the presence of fine-grained sediment. Mud was abundant enough in the Allt na Béiste palaeoenvironment to provide the necessary cohesion (e.g. Peakall et al., 2007; van Dijk et al., 2013) that is typically provided in more recent times by land plants and the supposedly more abundant fine-grained sediments. A possible mechanism with which to retain fine-grained sediments in the Allt na Béiste Member may have been the development of floodplain ponds promoted by local subsidence as a result of the compaction of the underlying lacustrine, fine-grained deposits of the Diabaig

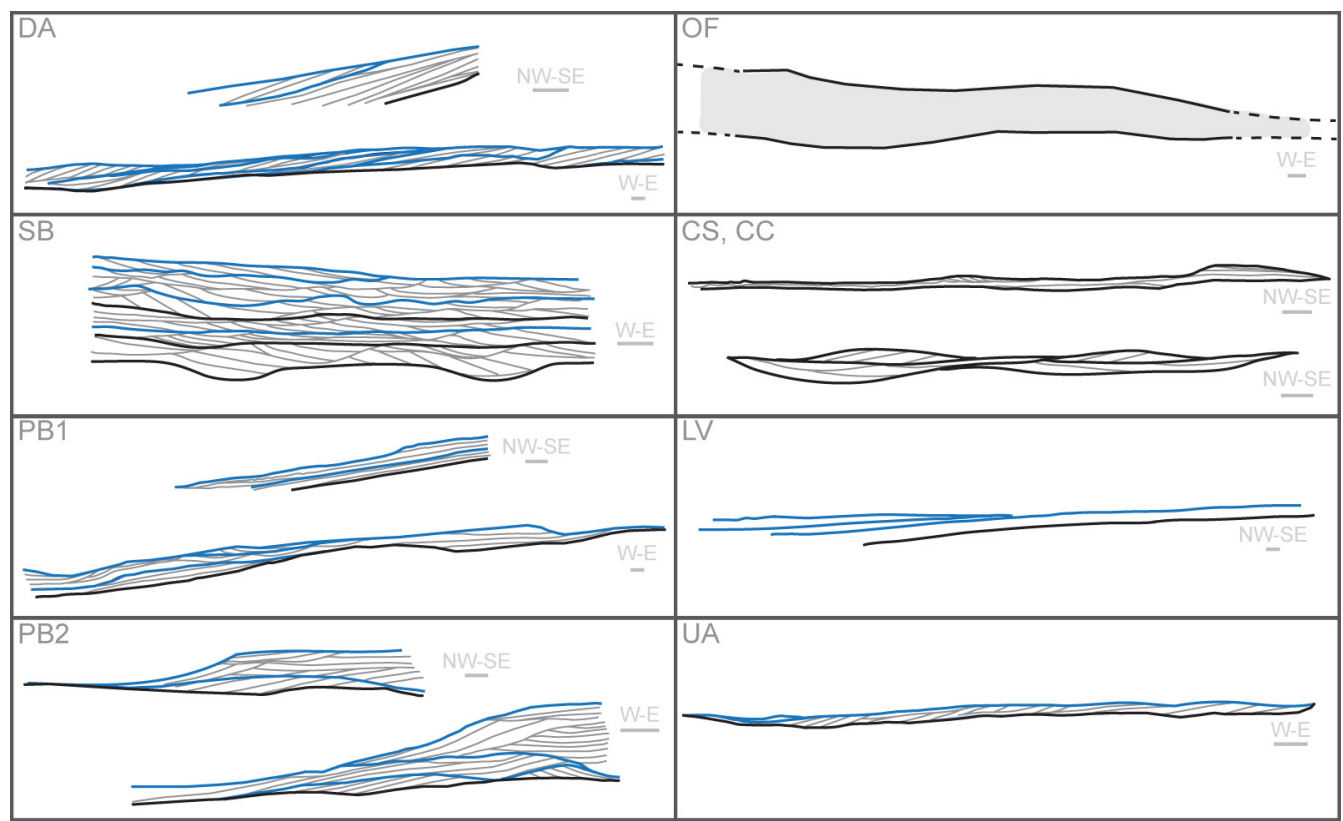

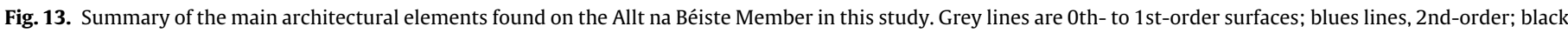
lines, 3rd- to 5th-order surfaces. 
Formation. These were sandwiched between the underlying Lewisian basement and the overlying Applecross Formation, with such compaction potentially having triggered the mobilization of sandstone dykes. The development of such floodplain ponds may have promoted suspended load deposition, leading to higher proportion of fine-grained sediments in the alluvial plain, with consequent increase in cohesion.

The specific characteristics of the Allt na Béiste Member sedimentology suggest some differences from systems where channel stability is contributed by the stabilizing effects of roots. The common occurrence of small-scale crevasse-splay deposits (Fig. 9) suggests that levée ruptures may have been more frequent. The common occurrence of fine-grained drapes preserving threedimensional dune bedforms in channel deposits, together with abundant intraformational mudclasts, indicates frequent flowregime fluctuations, which may have resulted from reduced runoff control compared to modern-day systems. Flat-bedded depositional surfaces are, however, rare, indicating that in-channel flow was rarely shallow or fast enough to produce and preserve them. Extreme flow-regime fluctuations represent a possible trigger for liquefaction and soft-sediment deformation in the upper successions of the Applecross Formation (see Owen and Santos, 2014).

Our data suggest that floodplains during the deposition of the Allt na Béiste Member were repeatedly combed by sinuous channels, the abandonment of which was probably cyclic, as recorded by the juxtaposition of floodplain deposits on channel deposits, as observed in Figs. 4 and 9, with erosional channel sandbodies at the base grading upwards to floodplain fines and splay sandstones. The absence of in situ mudcracks suggests a possible humid climate, or lack of subaerial exposure due to the presence of flooded regions of the alluvial plain. The preservation of numerous small-scale crevasse splays, channels and levées - architectural elements that are under-represented in pre-vegetation compared with post-vegetation river deposits (O'Brien and Wells, 1986; Long, 2011) - may indicate that non-vegetated point-bars were so poorly-stabilized that they were relatively low in height and slope, allowing the more frequent development of smaller crevasse channels. Either this situation was very rare in the Precambrian, or its preservation potential was very low. In fact, the $\sim 190$ m thickness of such deposits in comparison with the overlying $>6 \mathrm{~km}$ of Applecross Formation reflects the difficulties of preserving Precambrian heterolithic fluvial deposits. Pre-Silurian crevasse-splay deposits have not previously been positively identified (Long, 2011). Pre-vegetation levées were probably highly prone to erosion, so that crevasses could occur more readily, but the non-stabilized nature of the floodplains meant that crevasse splays could rapidly be eroded during floods so that their preservation potential was very low. Because thin soils are characterized by low total water storage capacity, runoff hydraulics are controlled by surface roughness, and Hortonian flows are controlled by infiltration rate and precipitation rate (North and Davidson, 2012), it is accepted that the paucity of well-developed soils in pre-Silurian fluvial deposits (Long, 2011) implies rapid runoff flow and fast erosion of hinterland (e.g. Long, 2006; Eriksson et al., 2006). But soils were preserved along the unconformity between the Torridonian sandstones and the Lewisian metamorphic rocks despite the absence of land plants acting as chemical-weathering agents (Retallack and Mindszenty, 1994). These palaeosols are the oldest known palaeosols in the British Isles and developed penecontemporaneously with the deposition of the Applecross Formation (Williams and Schmidt, 1997). They present chemical characteristics similar to modern-day soils developed under moderately humid climate (Williams, 1968). These conditions potentially influenced the nature of runoff rates after precipitation events, may have provided additional fine-grained sediments, and further contributed to buffering discharge rates in the Allt na Béiste river system. Other potential control may include influences of microbial mats (Noffke, 2009), which although no evidence of these were observed in this study, they have been described near the present study area in the underlying Diabaig Formation in fresh-water lake system deposits (Prave, 2002) and such microbial ecosystems were already adapted to low light levels and prolonged exposure to the air (Callow et al., 2011), and studies on microfossil assemblages from suggest that non-marine eukaryotes were thriving in subaerial and freshwater aquatic habitats during the deposition of the Torridon Group (Strother et al., 2011).

\subsection{Implications for fluvial style in the Precambrian: causes of meandering in pre-vegetation river systems}

The largest interval of the continental sedimentary environment's record was characterized by relatively discrete interactions between life and continental sedimentary processes (e.g. Gehling, 1999; Buougri and Porada, 2007; Noffke, 2009; Parizot et al., 2005), while facies models to account for the interpretation of different fluvial styles are largely based on modern day analogues (e.g. Jackson, 1978; Miall, 1996, 2013; Bridge, 2003). The behaviour of river systems can be influenced by vegetation density (Braudrick et al., 2009; Tal and Paola, 2007) and other interactions between geomorphic processes and ecosystems (Rice et al., 2012, Stoffel et al., 2013), to the extent that they do not provide reliable analogues for river systems that pre-date the advent of land vegetation. Land vegetation only developed significantly after the Ordovician (Wellman, 2010), and probably did not impact significantly on sedimentary processes until the Late Devonian, when roots were able to penetrate considerable depths into the substrate (Algeo et al. 1998), becoming an important control on sedimentary processes by Carboniferous times (Gastaldo and Degges, 2007; Gibling et al., 2010; Davies and Gibling, 2013). The presence of laterally-accreted heterolithic point bars and relatively thick overbank fine-grained deposits in the Allt na Béiste Member indicates that sinuous, meandering channels were able to comb stable floodplains at that time. A variety of controls can induce rivers to develop sinuous, singlethread channels, including: ( $i$ ) the presence of vegetation (Schumm, 1968; Tal and Paola, 2007); (ii) the availability of fine-grained sediment, adding cohesion to the depositional system (Sweet, 1988; Peakall et al., 2007; van Dijk et al., 2013); and (iii) dynamics between discharge rates, sediment supply and alluvial-plain gradients (Nanson and Huang, 2008; Lazarus and Constantine, 2013). Recent observations of meandering palaeochannel planforms on Mars (e.g. Nußbaumer, 2009; Schon et al., 2012; Matsubara et al., 2015) demonstrate that meandering channel systems are not exclusively linked to the interaction of alluvial processes with terrestrial life.

Several factors may have contributed to the availability of fine-grained, cohesive sediment that enabled the development of isolated, meandering channels and stable floodplains in the Allt na Béiste Member. (1) Legacy of the Diabaig Formation. Lewisian palaeovalleys filled by Diabaig Formation sediments resulted in low-gradient alluvial plains. Localized subsidence that may have been driven by differential compaction of the underlying lacustrine sediments promoted the development of floodplain ponds on the alluvial plain, providing environments that allowed for suspended-load deposition, resulting on relatively large amounts of fine-grained sediment available for reworking. This setting is similar to that inferred for meandering channels in the Jezero crater on Mars (Schon et al., 2012). (2) Climate-related enhanced weathering. Enhanced chemical weathering under warm, wet climates may have increased the availability of fine-grained sediment. This is consistent with the sub-humid and seasonal palaeoclimate inferred for the basal Torridon Group from palaeosol analysis of the unconformity between Lewisian metamorphic rocks and the Applecross 
Formation (Retallack and Mindszenty, 1994). (3) Basin evolution. High subsidence rates and/or high base levels may have led to the development of isolated channels and relatively thick floodplain deposits (e.g. Allen, 1974; Wright and Marriott, 1993). These factors did not persist into the deposition of the main Applecross Formation, which was influenced by the low availability of finegrained sediments and/or environmental conditions leading to the by-passing of such sediments to extrabasinal areas.

Laterally extensive silt and clay deposits in the Mesoproterozoic Belt Supergroup were interpreted as distal low-gradient, finegrained floodplain deposits by Winston (1978). They accumulated on the hanging-wall of the basin in an unconfined setting, and their preservation was controlled by sea-level fluctuations, demonstrating that mud could accumulate in pre-vegetation times under appropriate conditions. Other examples include fining-upward cycles and lateral accretion surfaces interpreted as meandering fluvial and fluvio-volcanic deposits from the Early Proterozoic Hatches Creek Group in central Australia (Sweet, 1988).

The Allt na Béiste Member of the basal Applecross Formation represents an example of a rarely preserved pre-vegetation palaeoenvironment. One comparable example is the $1.4 \mathrm{Ga}$ Sibley Group in Canada (Fralick and Zaniewski, 2012), although that study is not based on three-dimensional analysis. The preservation of such fine-grained alluvial deposits confirms interpretations by Ronov (1964) and Dalrymple et al. (1985) that other environmental controls are responsible for the uncommon preservation of fine-grained sediments in pre-vegetation alluvial environments, and that fine-grained sediment was available despite the lower chemical weathering rates due to the absence of vegetation.

\subsection{Significance of soft-sediment deformation structures}

Synsedimentary soft-sediment deformation structures in channel deposits, observed in series of cosets with upwardly-increasing deformation disrupted by erosional surfaces (Fig. 3A; cf. Santos et al., 2012), point to liquefaction driven by sudden pore-pressure build-up enabling deformation by current shear. Other examples relate to upwardly directed stresses deforming previously deposited, saturated sediments that were buried prior to deformation, which indicate a fluctuating water table and may have been triggered by flash-floods, sudden variations in flow regime or seismic activity (Owen et al., 2011; Owen and Moretti, 2011). Soft-sediment deformation structures in floodplain deposits are commonly related to the interruption of upward-directed porefluid flow by permeability barriers. This scenario may have triggered fluidization events recorded by small-scale clastic dykes. Their abundance suggests intense tectonism immediately after deposition and before diagenesis, and structural analysis indicates a NW/SE extensional palaeostress field. These dykes may also indicate compaction of the underlying Diabaig Formation contemporarily to the Allt na Béiste Member deposition.

Although soft-sediment deformation structures are much less abundant and smaller in scale in the Allt na Béiste Member than in the overlying part of the Applecross Formation (e.g. Owen, 1995, 1996), their presence, particularly in the floodplain facies, points to a near-surface water table (cf. Fralick and Zaniewski, 2012), supporting the interpretation of a wet palaeoclimate inferred from the absence of in situ mudcracks.

\subsection{Significance of the Diabaig-Applecross boundary}

Kinnaird et al. (2007) noted that the contact between the Diabaig and Applecross Formations "commonly displays erosive channelling and marks a sharp increase in grain size" and suggested that it represents an unconformity. Most basal bounding surfaces in the Applecross Formation are erosional, however (cf. Williams,
1966), and in the Allt na Béiste Member they represent contacts between channel and floodplain deposits. We therefore find no evidence in the Diabaig section for a significant unconformity at this stratigraphical level. On the contrary, the sedimentary facies are entirely consistent with a gradational succession of palaeoenvironments from mudstone-dominated lacustrine deposits in the Diabaig Formation through the heterolithic meandering fluvial systems of the Allt na Béiste Member to the braided fluvial systems represented in the pebbly sandstones of the main part of the Applecross Formation.

\subsection{Study of fluvial architecture in areas of limited exposure}

Techniques for the reconstruction of fluvial dynamics in conglomeratic and sand-prone deposits involving mapping sedimentary features onto multi-photograph, high-resolution mosaics (Allen, 1963; Miall, 1996, 2013) are not readily applied to mudprone successions that are typically less well exposed, particularly away from coastlines in areas such as the glacially eroded northwest of Scotland, where finer grained and heterolithic facies may be obscured by soil and bog. This highlights the need for new studies of pre-Silurian (pre-vegetation) heterolithic fluvial deposits preserved in scattered outcrops. Not surprisingly, the most detailed description of pre-vegetation floodplain deposits to date (Fralick and Zaniewski, 2012) is from borehole core analysis.

\section{Conclusions}

The Allt na Béiste Member differs from the overlying successions of the Applecross Formation in preserving many fluvial forms that are uncommon in Precambrian, pre-vegetation fluvial deposits, including point-bar deposits and relatively thick floodplain deposits, indicating that channels with sinuous planforms migrated laterally across stable floodplains. These floodplain deposits offer a glimpse of the depositional processes that prevailed on barren floodplains and indicate the presence of more complex alluvial environments than previously envisaged for Precambrian and pre-Silurian depositional systems. Possible controls for the preservation of such architecture include the presence of palaeovalleys filled by previous lacustrine and fluvial systems leading to low gradients, the availability of fine-grained sediment from highly-weathered basement with well-developed soils which also contributed to lower rates of runoff, and local subsidence resulting from differential compaction of previously deposited sediments. Structural data on fractures and associated soft-sediment deformation structures reveal an overall NW/SE extensional palaeostress field during the deposition of the Applecross Formation.

Pre-vegetation sinuous channel systems could develop as long as silt and mud provided sufficient channel cohesion and/or gradients and discharges were low. The point bar deposits coupled with the preservation of relatively thick floodplain deposits described here from the Allt na Béiste Member suggest that discharge rates prior to the Silurian were not restricted to the higher values proposed by previous works on pre-vegetation fluvial deposits (Schumm, 1968). Flows were not necessarily restricted to poorlyconfined channels, and channel bank cohesion was sufficient to stabilize single channels. Although meandering rivers were able to develop, they were potentially short-lived and had low preservation potential. This can be observed when comparisons are made between the thickness of the Allt na Béiste Member (max. $190 \mathrm{~m}$ ) and the main Applecross Formation $(>3 \mathrm{~km}$ ), in which the depositional architecture and facies are similar to most pre-vegetation fluvial systems described in the literature.

These results indicate that pre-vegetation alluvial environments were more complex than predicted by current models, in agreement with recently published papers (e.g., Long, 2011; Santos 
et al., 2014; Ielpi and Ghinassi, 2015; Ielpi and Rainbird, 2015). Importantly, they could present more fine-grained sediments than previously envisaged. The limited thickness of the Allt na Béiste Member with its unusual architecture in comparison with the thicker upper successions of the Applecross Formation suggests that in non-vegetated systems such fluvial styles were unlikely to be preserved or were highly unstable and short-lived.

These findings contribute to the understanding of fluvial processes prior to the evolution of land plants. The availability of fine-grained sediments was probably related to enhanced weathering, and their paucity in most Precambrian fluvial systems is probably related to controls such as sediment bypass to distal areas and flashy floods. The preservation of heterolithic and fine-grained sediments in pre-vegetation fluvial systems is more likely to be related to factors such as low-gradient fluvial profiles, mud-prone source rocks, and suspended-load. Further detailed outcrop-based studies on pre-vegetation heterolithic fluvial deposits are needed to widen the spectrum of pre-vegetation fluvial deposits to a more comprehensive and representative data set with which to develop further understanding of the evolution of rivers through geological time. We suggest that it is still too early to establish robust models for such a large period of time when continental environments were barren of macroscopic life.

\section{Acknowledgments}

We thank Darrel Long for detailed comments on an early draft of this paper. The comments of Editor Randall Parrish and two anonymous reviewers helped to improve the manuscript. The São Paulo Research Foundation is thanked for a post-doctoral scholarship to the senior author (FAPESP 2014/13937-3). Nigel Mountney, Jeff Peakall, Claudio Riccomini, and Mario Luis Assine are thanked for helpful discussions. Patrícia Magalhães and Dave Ellis are thanked for valuable help during fieldwork.

\section{References}

Algeo, T.J., Scheckler, S.E., Scott, A.C., 1998. Terrestrial-Marine teleconnections in the Devonian, links between the evolution of land plants, weathering processes, and marine anoxic events, and discussion. Philos. Trans. R. Soc. Lond. Biol. Sci. 353 (1365), 113-130.

Allen, J.R.L., 1963. The classification of cross-stratified units with notes on their origin. Sedimentology 2, 93-114.

Allen, J.R.L., 1964. Studies in fluviatile sedimentation: six cyclothems from the lower Old Red Sandstone, Anglo-Welsh Basin. Sedimentology 3, 163-198.

Allen, J.R.L., 1965. The sedimentation and palaeogeography of the Old Red Sandstone of Anglesey, North Wales. Proc. Yorks. Geol. Soc. 35, 139-185.

Allen, J.R.L., 1974. Sedimentology of the Old Red Sandstone (Siluro-Devonian) in the Clee hills area, Shropshire, England. Sediment. Geol. 12, 73-167.

Baas, J.H., 2000. EZ-ROSE: a computer program for equal-area circular histograms and statistical analysis of two-dimensional vectorial data. Comput. Geosci. 26, $153-166$.

Braudrick, C., Dietrich, W., Leverich, G., Sklar, L., 2009. Experimental evidence for the conditions necessary to sustain meandering in coarse-bedded rivers. Proc. Natl. Acad. Sci. U. S. A. 106, 16936-169941.

Bridge, J., 2003. Rivers and Floodplains. Blackwell Science Ltd., Oxford, England.

Buougri, E., Porada, H., 2007. Complex structures associated with siliciclastic biolaminites. In: Schieber, J., Bosem, P.K., Eriksson, P.G., Banerjee, S., Altermann, W., Catuneanu, O. (Eds.), Atlas of Microbial Mat Features Preserved Within the Clastic Record. Elsevier.

Callow, R.H.T., Battison, L., Brasier, M.D., 2011. Diverse microbially induced sedimentary structures from 1 Ga lakes of the Diabaig Formation, Torridon Group, northwest Scotland. Sediment. Geol. 239 (3-4), 117-128.

Corenblit, D., Steiger, J., 2009. Vegetation as a major conductor of geomorphic changes on the Earth surface: toward evolutionary geomorphology. Earth Surf. Process. Landf. 34, 891-896.

Cotter, E., 1978. The evolution of fluvial style, with special reference to the central Appalachian Palaeozoic. In: Miall, A.D. (Ed.), Fluvial Sedimentology, vol. 5 of Can. Soc. Petrol. Geol. Mem. Canadian Society of Petroleum Geologists, pp. 361-384.

Dalrymple, R., Narbonne, G., Smith, L., 1985. Eolian action and the distribution of Cambrian shales in North America. Geology 13, 607-610.

Davies, N.S., Gibling, M.R., 2010. Cambrian to Devonian evolution of alluvial systems: the sedimentological impact of the earliest land plants. Earth Sci. Rev. 98, $171-200$.
Davies, N.S., Gibling, M.R., 2013. The sedimentary record of Carboniferous rivers: continuing influence of land plant evolution on alluvial processes and Palaeozoic ecosystems. Earth Sci. Rev. 120, 40-79.

Eriksson, P.G., Condie, K.C., Tirsgaard, H., Mueller, W.U., Altermann, W., Miall, A.D. Aspler, L.B., Catuneanu, O., Chiarenzelli, J.R., 1998. Precambrian clastic sedimentation systems. Sediment. Geol. 120, 5-53.

Eriksson, P.G., Bumby, A.J., Brümer, J.J., Neut, M., 2006. Precambrian fluvial deposits: enigmatic palaeohydrological data from the c. 2-1.9 Ga Waterberg Group, South Africa. Sediment. Geol. 190, 25-46.

Eriksson, P.G., Banerjee, S., Catuneanu, O., Corcoran, P.L., Eriksson, K.A., Hiatt, E.E., Laflamme, M., Lenhardt, N., Long, D.G.F., Miall, A.D., Mints, M.V., Pufahl, P.K. Sarkar, S., Simpson, E.L., Williams, G.E., 2013. Secular changes in sedimentation systems and sequence stratigraphy. Gondwana Res. 24, 468-489.

Fralick, P., Zaniewski, K., 2012. Sedimentology of a wet, pre-vegetation floodplain assemblage. Sedimentology 59 (3), 1030-1049.

Fuller, A.O., 1985. A contribution to the conceptual modelling of pre-Devonian fluvial systems: Geological Society of South Africa. Transactions 88, 189-194.

Gastaldo, R., Degges, C., 2007. Sedimentology and paleontology of a Carboniferous log jam. J. Coal Geol. 69, 103-118.

Gehling, J.G., 1999. Microbial mats in terminal Proterozoic siliciclastics: Ediacaran death masks. Palaios 14, 40-57.

Gibling, M.R., Bashforth, A.R., Falcon-Lang, H.J., Allen, J.P., Fielding, C.R., 2010. Log jams and flood sediment buildup caused channel abandonment and avulsion in the Pennsylvanian of Atlantic Canada. J. Sediment. Res. 80, 268-287.

Gibling, M.R., Davies, N.S., Falcon-Lang, H.J., Bashforth, A.R., DiMichele, W.A., Rygel, M.C., Ielpi, A.R., 2014. Palaeozoic co-evolution of rivers and vegetation: a synthesis of current knowledge. Proc. Geol. Assoc. 125 (5-6), 524-533.

Hjellbakk, A., 1997. Facies and fluvial architecture of a high-energy braided river: the Upper Proterozoic Seglodden Member, Varanger Peninsula, northern Norway. Sediment. Geol. 114, 131-161.

Ielpi, A., Ghinassi, M., 2015. Planview style and palaeodrainage of Torridonian channel belts: Applecross Formation, Stoer Peninsula, Scotland. Sediment. Geol. 325, $1-16$.

Ielpi, A., Rainbird, R.H., 2015. Architecture and morphodynamics of a 1.6 Ga fluvial sandstone: Ellice Formation of Elu Basin, Arctic Canada. Sedimentology, http:// dx.doi.org/10.1111/sed.12211.

Jackson, R.G., 1978. Preliminary evaluation of lithofacies models for meandering alluvial streams. In: Miall, A. (Ed.), Fluvial Sedimentology, vol. 5. Canadian Society of Petroleum Geoscientists, Calgary, Canada, pp. 543-576.

Kinnaird, T.C., Prave, A.R., Kirkland, C.L., Horstwood, M., Parrish, R., Batchelor R.A., 2007. The late Mesoproterozoic-early Neoproterozoic tectonostratigraphic evolution of NW Scotland: the Torridonian revisited. J. Geol. Soc. 164, 541-551.

Krabbendam, M., Prave, T., Cheer, D., 2008. A fluvial origin for the Neoproterozoic Morar Group, NW Scotland: implications for Torridon-Morar Group correlation and the Grenville Orogen foreland basin. J. Geol. Soc. 165, 379-394.

Lazarus, E., Constantine, J., 2013. Generic theory for channel sinuosity. Proc. Natl. Acad. Sci. 110, 8447-8452.

Leeder, M.R., 1973. Fluviatile fining-upwards cycles and the magnitude of palaeochannels. Geol. Mag. 110, 265-276.

Long, D.G.F., 1978. Proterozoic stream deposits: some problems of recognition and interpretation of ancient sandy fluvial systems. In: Miall, A.D. (Ed.), Fluvial Sedimentology, vol. 5 of Memmoir. Canadian Society Petroleum Geology, Calgary, pp. 313-342.

Long, D.G.F., 2004. Precambrian rivers. In: Eriksson, P.G., Altermann, W., Nelson, D.R. Mueller, W.U., Catuneanu, O. (Eds.), The Precambrian Earth: Tempos and Events. Elsevier, Amsterdam, pp. 660-663.

Long, D.G.F., 2006. Architecture of pre-vegetation sandy-braided perennial and ephemeral river deposits in the Paleoproterozoic Athabasca Group, northern Saskatchewan, Canada as indicators of Precambrian fluvial style. Sediment. Geol. 190, 71-95

Long, D.G.F., 2011. Architecture and depositional style of fluvial systems before land plants: a comparison of precambrian, early Paleozoic modern river deposits. In: Davidson, S., Leleu, S., North, C. (Eds.), From River to Rock Record: the Preservation of Fluvial Sediments and their Subsequent Interpretation, vol. 97 of SEPM Special Publications. SEPM, pp. 37-61.

Lowe, D.R., 1975. Water escape structures in coarse-grained sediments. Sedimentology 22, 157-204.

Marconato, A., Almeida, R.P., Turra, B., Fragoso-Cesar, A.R.S., 2014. Pre-vegetation fluvial floodplains and channel-belts in the Late Neoproterozoic-Cambrian Santa Bárbara group (Southern Brazil). Sediment. Geol. 300, 49-61.

Matsubara, Y., Howard, A.D., Burr, D.M., Williams, R.M.E., Dietrich, W.E., Moore, J.M., 2015. River meandering on Earth and Mars: A comparative study of Aeolis Dorsa meanders, Mars and possible terrestrial analogs of the Usuktuk River, AK, and the Quinn River, NV. Geomorphology 240, 102-120, http://dx.doi.org/10.1016/ j.geomorph.2014.08.031.

Miall, A.D., 1979. Tertiary fluvial sediments in the Lake Hazen intermontane basin, Ellesmere Island, Arctic Canada. Geol. Surv. Can. Pap. 79, 9.

Miall, A.D., 1996. The Geology of Fluvial Deposits: Sedimentary Facies, Basin Analysis and Petroleum Geology. Springer-Verlag, Inc., Heidelberg.

Miall, A.D., 2013. Fluvial Depositional Systems. Springer Geology. Springer, Switzerland.

Nanson, G.C., Huang, H.Q., 2008. Least action principle, equilibrium states, iterative adjustment and the stability of alluvial channels. Earth Surf. Process. Landf. 33, 923-942.

Nemec, W., 1988. The shape of the rose. Sediment. Geol. 59, 149-152. 
Nicholson, P., 1993. A basin reappraisal of the Proterozoic Torridon Group, northwest Scotland. In: Frostick, L., Steel, R. (Eds.), Tectonic Controls and Signatures in Sedimentary Successions, vol. 20. International Association of Sedimentologists, Special Publications, pp. 183-202.

Noffke, N., 2009. The criteria for the biogeneicity of microbially induced structures (MISS) in Archean and younger, sandy deposits. Earth Sci. Rev. 96 (3), 173-180.

North, C.P., Davidson, S.K., 2012. Unconfined alluvial flow processes: recognition and interpretation of their deposits, and the significance for palaeogeographic reconstruction. Earth Sci. Rev. 11, 199-223.

Nußbaumer, J., 2009. Liquid water formed scroll bars in river meanders from decades in Elysium planitia, mars. In: 40th Lunar and Planetary Science Conference.

O’Brien, P.E., Wells, A.T., 1986. A small, alluvial crevasse splay. J. Sediment. Petrol. 56 (6), 875-879.

Owen, G., 1995. Soft sediment in Upper Proterozoic Torridonian Sandstones (Applecross Formation) at Torridon, Northwest Scotland. J. Sediment. Res. A65 (3), 495-504.

Owen, G., 1996. Anatomy of a water-escape cusp in Upper Proterozoic Torridon Group sandstones, Scotland. Sediment. Geol. 103, 117-128.

Owen, G., Moretti, M., 2011. Identifying triggers for liquefaction-induced softsediment deformation in sands. Sediment. Geol. 235, 141-147.

Owen, G., Santos, M.G.M., 2014. The Neoproterozoic Torridonian of NW Scotland: fluvial facies and soft-sediment deformation in a pre-vegetation river system. Proc. Geol. Assoc. 125, 511-523.

Owen, G., Moretti, M., Alfaro, P., 2011. Recognising triggers for soft-sediment deformation: current understanding and future directions. Sediment. Geol. 235, $133-140$.

Parizot, M., Eriksson, P.G., Aifa, T., Sarkar, S., Banerjee, S., Catuneanu, O., Altermann, W., Bumby, A.J., Bordy, E.M., van Rooy, J.L., Boshoff, J., 2005. Suspected microbial matrelated crack-like sedimentary structures in the Palaeoproterozoic Magaliesberg Formation sandstone, South Africa. Precambrian Res. 138, 274-296.

Peach, B.N., Horne, J., Gunn, W., Clough, C.T., Hinxman, L.W., Teall, J.J.H., 1907. The geological structure of the northwest highlands of Scotland. Technical report, Geological Survey, Great Britain.

Peakall, J., Ashworth, P.J., Best, J.L., 2007. Meander-bend evolution, alluvial architecture, and the role of cohesion in sinuous river channels: a flume study. J. Sediment. Res. 77, 197-212.

Prave, A.R., 2002. Life on land in the Proterozoic: evidence from the Torridonian rocks of northwest Scotland. Geology 30, 811-814

Rainbird, R.H., Hamilton, M.A., Young, G.M., 2001. A unifying model for the Torridon Group (early Neoproterozoic), NW Scotland: product of post-Grenvillian extensional collapse. J. Geol. Soc. Lond. 158, 15-27.

Retallack, G.J., Mindszenty, A., 1994. Well-preserved Late Precambrian paleosols from northwest Scotland. J. Sediment. Res. A64, 264-281.

Rice, S., Stoffel, M., Turowski, J.M., Wolfi, A., 2012. Disturbance regimes at the interface of geomorphology and ecology. Earth Surf. Process. Landf. 37, 1678-1682.

Røe, S.-L., 1987. Cross-strata and bedforms of probable transitional dune to upperstage planebed origin from a Late Precambrian fluvial sandstone, northern Norway. Sedimentology 34, 89-101.

Røe, S.-L., Hermansen, M., 1993. Processes and products of large. Late Precambrian sandy rivers in northern Norway. Spec. Publ. Int. Assoc. Sedimentol. 17, $151-166$.

Ronov, A.B., 1964. Common tendencies in the chemical evolution of the Earth's crust, ocean and atmosphere. Geochem. Int. 4, 713-737.

Santos, M.G.M., Almeida, R.P., Mountney, N.P., Fragoso-Cesar, A.R.S., 2012. Seismites as a tool in the palaeoenvironmental reconstruction of fluvial deposits: the Cambrian Guarda Velha Formation, southern Brazil. Sediment. Geol. 277-278, 52-60.

Santos, M.G.M., Almeida, R.P., Godinho, L.P.S., Marconato, A., Mountney, N.P., 2014. Distinct styles of fluvial deposition in a Cambrian rift basin. Sedimentology 61, $881-914$.

Schon, S.C., Head, J.W., Fassett, C.I., 2012. An overfilled lacustrine system and progradational delta in Jezero crater, Mars: implications for Noachian climate. Planet. Pace Sci. 67, 28-45.

Schumm, S.A., 1968. Speculations concerning the palaeo-hydraulic controls of terrestrial sedimentation. Geol. Soc. Am. Bull. 79, 1573-1588.
Selley, R.C., 1965. Diagnostic characters of fluviatile sediments of the Torridonian Formation (Precambrian) of Northwest Scotland. J. Sediment. Petrol. 35 (2), $366-380$.

Selley, R.C., 1969. Torridonian alluvium and quicksands. Scott. J. Geol. 5, 328-346.

Sønderholm, M., Tirsgaard, H., 1998. Proterozoic fluvial styles: responses to changes in accommodation space (Rivieradal Sandstones, eastern North Greenland). Sediment. Geol. 120, 257-274.

Stewart, A.D., 1969. Torridonian Rocks of Scotland Reviewed. AAPG. Memoirs 12, 595-608.

Stewart, A.D., 1982. Late Proterozoic rifting in NW Scotland: the genesis of the Torridonian. J. Geol. Soc. Lond. 139, 413-420.

Stewart, A.D., 1988. The Sleat and Torridon groups. In: Winchester, J.A. (Ed.), Later Proterozoic stratigraphy of the northern Atlantic regions. Blackie and Son Ltd. Glasgow, Scotland.

Stewart, A.D., 2002. The later Proterozoic Torridonian rocks of Scotland: their sedimentology, geochemistry and origin. Number 24 in Geological Society Memoir. Geological Society, London, England.

Stoffel, M., Rice, S., Turowski, J.M., 2013. Process geomorphology and ecosystems: disturbance regimes and interactions. Geomorphology 202, 1-3.

Strother, P.K., Battison, L., Brasier, M.D., Wellman, C.H., 2011. Earth's earliest nonmarine eukaryotes. Nature 473, 505-509.

Sweet, I., 1988. Early Proterozoic stream deposits: braided or meandering - evidence from central Australia. Sediment. Geol. 58, 277-293.

Tal, M., Paola, C., 2007. Dynamic single-thread channels maintained by the interaction of flow and vegetation. Geology 35, 347-350.

Thomas, R., Smith, D., Wood, J., Visser, J., Calverley-Range, E., Koster, E., 1987. Inclined heterolithic stratification - terminology, description, interpretation and significance. Sediment. Geol. 53, 123-179.

Tirsgaard, H., Øxnevad, I.E.I., 1998. Preservation of pre-vegetational fluvio-aeolian deposits in a humid climatic setting: an example from the Middle Proterozoic Eriksfjord Formation, southwest Greenland. Sediment. Geol. 120, 295-317.

Turnbull, M.J.M., Whitehouse, M.J., Moorbath, S., 1996. New isotopic age determinations for the Torridonian, NW Scotland. J. Geol. Soc. 153, 694-955.

van Dijk, W.M., van de Lageweg, W.I., Kleinhans, M.G., 2013. Formation of a cohesive floodplain in a dynamic experimental meandering river. Earth Surf. Process. Landf. 38 (13), 1096-9837, http://dx.doi.org/10.1002/esp.3400.

Wellman, C.H., 2010. The invasion of the land by plants: when and where? New Phytol. 188, 306-309.

Went, D.J., 2005. Pre-vegetation alluvial fan facies and processes: an example from the Cambro-Ordovician Rozel Conglomerate Formation, Jersey, Channel Islands. Sedimentology 52, 693-713

Went, D.J., 2013. Quartzite development in early Palaeozoic nearshore marine environments. Sedimentology 60, 1036-1058.

Williams, G.E., 1966. Palaeogeography of the Torridonian Applecross Group. Nature 209, 1303-1306.

Williams, G.E., 1968. Torridonian weathering, and its bearing on Torridonian palaeoclimate and source. Scott. J. Geol. 4, 164-184.

Williams, G.E., 1969. Characteristics and origin of a Precambrian pediment. J. Geol. 77 (2), 183-207.

Williams, G.E., 2001. Neoproterozoic (Torridonian) alluvial fan succession, northwest Scotland, and its tectonic setting and provenance. Geol. Mag. 138 (4) 471-494.

Williams, G.E., Foden, J., 2011. A unifying model for the Torridon Group (early Neoproterozoic) NW Scotland: product of post-Grenvillian extensional collapse. Earth Sci. Rev. 108, 34-49.

Williams, G.E., Schmidt, P.W., 1997. Palaeomagnetic dating of sub-Torridon Group weathering profiles, NW Scotland: verification of Neoproterozoic palaeosols. J. Geol. Soc. Lond. 154, 987-997.

Winston, D., 1978. Fluvial systems of the Precambrian belt supergroup, Montana and Idaho. In: Miall, A. (Ed.), Fluvial Sedimentology, vol. 5. Canadian Society of Petroleum Geologists Memoir, pp. 343-359.

Wolman, M.G., Brush, L.M., 1961. Factors controlling the size and shape of stream channels in coarse non-cohesive sands. USGS Professional Paper, vol. 282-G. U.S. Geological Survey, Washington, DC, pp. 183-210.

Wright, V.P., Marriott, S.B., 1993. The sequence stratigraphy of fluvial depositional systems: the role of floodplain sediment storage. Sediment. Geol. 86, 203-210. 